This item was submitted to Loughborough's Research Repository by the author.

Items in Figshare are protected by copyright, with all rights reserved, unless otherwise indicated.

\title{
The influence of the physical environment on self-recovery after disasters in Nepal and the Philippines
}

PLEASE CITE THE PUBLISHED VERSION

https://doi.org/10.1016/j.ijdrr.2020.101673

\section{PUBLISHER}

Elsevier Ltd

VERSION

AM (Accepted Manuscript)

\section{PUBLISHER STATEMENT}

This paper was accepted for publication in the journal International Journal of Disaster Risk Reduction and the definitive published version is available at https://doi.org/10.1016/j.ijdrr.2020.101673.

LICENCE

CC BY-NC-ND 4.0

\section{REPOSITORY RECORD}

Sargeant, S, A Finlayson, Tom Dijkstra, B Flinn, H Schofield, L Miranda Morel, J Twigg, E Lovell, V Stephenson, and BR Adhikari. 2020. "The Influence of the Physical Environment on Self-recovery After Disasters in Nepal and the Philippines". Loughborough University. https://hdl.handle.net/2134/12758381.v1. 


\section{The influence of the physical environment on self-recovery after disasters in Nepal and the Philippines}

S. Sargeant ${ }^{1}$, A. Finlayson, T. Dijkstra, B. Flinn, H. Schofield, L. Miranda Morel, J. Twigg, E. Lovell, V. Stephenson and B. R. Adhikari

\section{Abstract}

Following a disaster, the majority of families rebuild their homes themselves. In this paper, we consider how the physical environment influences such 'self-recovery' by investigating disasters in the Philippines (typhoons Haiyan in 2013 and Haima in 2016) and Nepal (the Gorkha earthquake 2015). Despite the many differences in the disaster contexts, there are some common barriers to self-recovery (and building back better) in a substantially changed and dynamic multi-hazard, postdisaster environment. These are related to changes in water supply (shortage or surplus), impacts of post-disaster geohazard events on infrastructure (particularly affecting transport) and the availability of technical advice. People face a broad spectrum of challenges as they recover and tackling these 'geo-barriers' may help to create a more enabling environment for self-recovery. The findings point to what needs to be in place to support self-recovery in dynamic physical environments, including geoscience information and advice, and restoration of infrastructure damaged by natural hazard events. Further research is necessary to understand the issues this raises for the shelter and geoscience communities, particularly around availability of geoscience expertise, capacity and information at a local scale.

Highlights

- Changes in the physical environment following a disaster have a significant influence on recovery

- An interdisciplinary approach yields a more complete view of self-recovery and how it is affected by the physical environment

- There are opportunities to support self-recovery if geoscientists, humanitarian practitioners and affected communities work together.

\section{Keywords}

Post-disaster recovery, Gorkha earthquake, Haiyan, Haima, physical environment

\section{Introduction}

The majority of families rebuild after a disaster using their own resources, or those immediately available to them, with little or no assistance from the international humanitarian community to encourage safer building practices (Twigg et. al. 2017). In recent years the term 'self-recovery' has been coined by the humanitarian shelter sector ${ }^{2}$ to describe this process. Actively supporting this process is now considered to be an appropriate and effective approach to post-disaster recovery and is recognised as a strategic approach by the Global Shelter Cluster in its 2018-22 strategy ${ }^{3}$. However, the process of self-recovery is not well understood and there is very little guidance on how to

\footnotetext{
${ }^{1}$ Corresponding author, slsa@bgs.ac.uk

2 The recovery of housing after rapid-onset disasters as well as protracted conflict and displacement is referred to as 'shelter' (e.g. Saunders, 2004).

${ }^{3}$ The shelter sector is coordinated by the Global Shelter Cluster, jointly led by the IFRC and UNHCR.
} 
conduct a project implemented by humanitarian actors that supports self-recovery. The provision of cash and technical assistance has been employed effectively to provide appropriate assistance to a large number of affected people (Parrack et al., 2014) but there are many other potential opportunities for supporting the process of self-recovery and lifting the barriers that hinder people's recovery paths.

The objective of this paper is to investigate how the physical environment affects disaster selfrecovery at a household and community level, and to more fully understand the challenges people face to recover (and build back better) in dynamic multi-hazard environments. There is currently very little published research on this and our study represents a first step towards developing a preliminary conceptual framework to explain the relationship between self-recovery and the physical environment, and how it can be supported. Recovery often takes place in multi-hazard environments, where high-frequency, low-magnitude events (e.g. localised flooding, landslides) are also part of the hazard landscape (Twigg et. al. 2017). These background hazards contribute towards extensive risk - a 'risk layer' that accounts for the risk of localised and recurrent, small-scale, low severity losses (Global Assessment Report, 2015, p 90) that is 'largely invisible' in terms of global loss modelling or reporting (ibid., p 93). Extensive risk will be strongly influenced by the landscape in which a disaster-affected community is located.

There are two aspects of self-recovery that must be recognised by external agencies (Twigg et al., 2017). The first is that it is an inevitable process: people are never passive and invariably embark on recovery activities long before external assistance arrives. The second is the notion of agency, or the right of families to autonomy and the freedom to choose their own recovery priorities. The role of assisting organisations in adopting a self-recovery approach is therefore to work closely with the affected population to help smooth the way to recovery. Supporting self-recovery aligns well with much of current humanitarian thinking. The 2016 World Humanitarian Summit ratified the commitments of the 'Grand Bargain', an agreement that sets out the changes needed in the way donors and aid organisations work to address the humanitarian financing gap (e.g. ICVA, 2017). The agreement to increase cash transfer programming, to a 'localisation' agenda and to a 'participation revolution', all endorse a more people-centred approach. Similarly, the 2015 Sendai Framework for Disaster Risk Reduction has 'Enhancing disaster preparedness for effective response and to "Build Back Better" in recovery, rehabilitation and reconstruction' as one of its four Priorities for Action ${ }^{4}$.

The challenge for the humanitarian shelter sector is how best to create an environment that supports self-recovery without compromising, or unduly influencing, a person's right to make their own decisions based on very real needs. A family may decide that paying off their debts, or not increasing their debt burden, or their children's education are equally as important as the need for a safe house. Similarly, issues such as access to and transport of materials or maintenance of livelihood may need to be in place before a family can choose to focus resources on rebuilding a safer home. The key point is that the affected person or family needs to be 'in the driving seat' rather than having particular interventions imposed from outside.

Relatively few investigations of the recovery process focus specifically on how it is shaped by the physical environment in which it takes place. One example is Liu et al. (2011) who studied the response to the Wenchuan earthquake. As a result of their findings, they recommend preearthquake analyses of geological hazards, and the hydrological and environmental impacts when planning for disaster recovery as well as siting emergency shelters. There are no examples that we

\footnotetext{
${ }^{4}$ https://www.unisdr.org/we/coordinate/sendai-framework
} 
know of that consider how self-recovery is affected by, or can be better supported within, different physical environments.

The Sphere Standards are a set of rights-based standards for humanitarian response (Sphere Association, 2018). The standards call for humanitarian activities to be guided by existing community hazard and risk assessments, and for consideration to be given to issues relating to safe siting, water, contamination, and infrastructure. A key action in the Shelter and Settlement Standard 2 is to "locate any new settlements a safe distance from actual/potential threats and minimise risks from existing hazards' (ibid.) and for rainfall and floodwater drainage to be considered in site selection. The environment is one of seven crosscutting issues identified in the World Bank's Post Disaster Needs Assessment Guidelines (PDNA) because it affects all aspects of human life (World Bank, 2017a). The objective of the environment aspect of the PDNA is 'to prepare a recovery strategy that guides the restoration of environment and natural resources damaged due to a disaster' (ibid., p 2). The guidelines emphasise the environmental impact of various hazards (typhoons, earthquakes, tsunami, floods, landslide and some volcanic hazards) but the strategies suggested for managing risk to livelihoods from these hazards during recovery are outlined in a general way (e.g. settlement and building regulations for earthquakes, erosion control practices and settlement regulation in the case of landslides and coastal zone regulations for typhoons). The Disaster Risk Reduction (DRR) PDNA guideline (World Bank, 2017b) highlights that additional hazards may threaten people as they recover and that 'measures... to correct, mitigate or reduce these threats should be identified and adopted as part of the recovery process' (ibid., p 12) but limited detailed guidance is given as to how this should be done.

In this paper, we present the findings from fieldwork carried out in a selection of rural and urban communities affected by three rapid-onset disasters: typhoons Haiyan (2013) and Haima (2016) in the Philippines, and the Gorkha earthquake in Nepal (2015). These sudden-onset disasters generated major humanitarian responses requiring significant recovery assistance programmes (e.g. Bhaby, 2015; Newby et al., 2015). The research has been carried out by a mixed team: multidisciplinary (social scientists, physical scientists, engineers) and multi-sector (CARE International - a humanitarian organisation, universities and research organisations, and a global think tank ). The examples that this study explores were chosen because the research team has prior experience of working in these countries and has links with communities through CARE's in-country partner organisations. Furthermore, in the Philippines, all barangays that we visited in the rural and periurban settings had been beneficiaries of CARE shelter and livelihood assistance. In Nepal, the sites were identified by the CARE Nepal team using criteria we provided because our aim was to visit communities located in diverse physical settings - some who had been the focus of a CARE intervention and others who had not (see Twigg et al, 2017 and Schofield et al., 2019 for further information). The fact that the communities were all located in a variety of physical environments allowed us to explore how this influences self-recovery.

Our findings show that there are some key 'geo-barriers' to self-recovery, and that addressing these might help to create an environment that better enables self-recovery in general (i.e. not just in terms of shelter). These findings are not inconsistent with what either the Sphere Standards or PDNA guidelines recommend but do provide a more detailed picture of what is necessary to support recovery at the very local level in different physical settings, and indications of where some of the challenges for humanitarians, geoscience and geoscientists may lie. 
Typhoons in the Philippines (Haiyan - 2013, Haima - 2016)

Typhoon Haiyan (named 'Yolanda' in the Philippines) is one of the most powerful typhoons to have made landfall in recorded history. It crossed the Visayas region on 8 November 2013, bringing sustained winds that reached $315 \mathrm{~km} / \mathrm{hr}$ (category 5 on the Saffir-Simpson hurricane wind scale), and a 72-hour rainfall total of up to $\sim 400 \mathrm{~mm}$. The typhoon also caused storm surges, flooding and landslides. The National Disaster Risk Reduction Management Council (NDRRMC) reported 6300 fatalities with more than 1000 people missing, and there were widespread impacts to infrastructure, and to the social and productive sectors (NDRRMC, 2014). Haiyan was the ninth tropical cyclone to make landfall over the Philippines in 2013, and was one of 720 tropical cyclones to enter the Philippine Area of Responsibility from 1970-2013 (NDRRMC, 2014). The exceptionally strong winds and faster than average forward motion, made Typhoon Haiyan an infrequent event with an estimated return period of 200 years (Takagi and Estaban, 2016).

Typhoon Haima (named 'Lawin' in the Philippines) crossed northern Luzon on 19 and 20 October 2016. It was classed as Category 4 on the Saffir-Simpson scale, and made landfall over Luzon's eastern coast bringing sustained wind speeds of $225 \mathrm{~km} / \mathrm{hr}$, and gusts of up to $315 \mathrm{~km} / \mathrm{hr}$ (NDRRMC, 2016). The typhoon was downgraded to Category 3 as it crossed over to Luzon's western coast. In northern Luzon, up to $250 \mathrm{~mm}$ of rain fell over a 72 hour period bringing flooding and landslides, which killed fourteen people. Over 90,000 houses were damaged (nearly 14,000 destroyed) and many roads and bridges became impassable (NDRRMC, 2016).

With the exception of the city of Tacloban, most of the housing damage from both typhoons was in a rural setting. Tacloban, a city of approximately 240,000, accounted for most of the death toll from Typhoon Haiyan because of the devastating storm surge (Lagmay et al., 2015). Almost all of the houses that were damaged or destroyed, in both urban and rural settings, were simple single-storey dwellings built of lightweight materials. Timber and bamboo structures, with plywood and woven bamboo screen cladding and pitched roofs of corrugated metal or local thatch (nipa) was the prevailing typology. Most were extremely vulnerable to storms and the damage to housing as a result of Typhoon Haiyan was immense with over half a million homes destroyed (REACH, 2013).

Gorkha earthquake - 2015, Nepal)

At 11:56 local time (06:11:26 UTC) on 25 April 2015, Nepal was struck by a large earthquake (7.8 $\mathrm{Mw})$. Geodetic observations of surface displacement indicate that the earthquake occurred on the Main Himalayan Thrust Fault. The earthquake was followed by hundreds of aftershocks, the largest one being a 7.3 Mw event to the east of Kathmandu on 12 May (Elliott et al., 2016; Kargel et al., 2016; Shrestha et al., 2016). Secondary/triggered hazards had a significant impact and highlighted some of the potential threats that exist in mountainous landscapes. The earthquake triggered new landslides (or reactivated older ones) and avalanches although only a few landslide dams were identified (Williams et al., 2018; Shrestha et al., 2016). Debris slides (a rapidly moving mass of unconsolidated rock and soil) were the most common type of failure with rock falls (individual boulders to large falls) more common on steeper slopes (Moss et al., 2015; Gnyawali et al., 2016; Roback et al., 2018).

Around 9,000 people were killed, tens of thousands injured and about a third of the country's population was affected (National Planning Commission, 2015). Approximately 100,000 people were displaced. The districts of Gorkha, Dhading, Rasuwa, Nuwakot, Sindhupalchowk, Dolakha and Ramechhap were located directly above the rupture and were worst affected (Shrestha et al., 2016). Destruction was widespread and residential and government buildings, schools and health facilities, 
agricultural land, infrastructure and recreational facilities were severely impacted (Sharma et al., 2018a, b). Rural areas in central and western Nepal were also cut off by damage to roads and other disruptions, which made it difficult to access these places in the immediate response (Shrestha et al., 2016). The total economic loss due to the earthquake was around USD 7 billion (ibid.). It is estimated that the earthquake caused $2.5-3.5 \%$ of the Nepalese population to be pushed into poverty (National Planning Commission, 2015).

\section{Methodology}

Two phases of fieldwork were undertaken in consecutive Global Challenges Research Fund projects the first funded by NERC-ESRC-AHRC's Building Resilience programme and the second through the British Academy's Cities and Infrastructure programme. The fieldwork for the first project (FebruaryMay 2017), focussed on rural communities in Nepal and the Philippines. Most of these had received some sort of assistance from humanitarian organisations. The fieldwork for the second project (April-June 2018) focussed on communities in urban or peri-urban settings in the same countries. Communities were identified using one or more proxy indicators for urban poverty proposed by Moser and Stein (2011) since people living in these areas might typically also be recipients of humanitarian aid. These factors included exposure to environmental hazards, volume and density of low quality building, deficiencies in service provision and tenure status.

The aim was to understand how the physical environment influences self-recovery and the challenges that people face in different landscapes. To do this, we classified the characteristic terrain or 'landsystem' within the overall landscape that a particular community occupied (cf. Griffiths, 2017). Landsystems mapping (also referred to as terrain characterisation) is a way to describe the nature of the physical aspects of the landscape and is often used for engineering purposes (ibid.) and can be used for natural hazard analysis (Griffiths, 2017). Landsystems are typically large areas (of the order of $100 \mathrm{~km}^{2}$ ) where there is 'a recurring pattern of landforms, soils, vegetation, geology and hydrological regimes' (ibid., p3). For the Philippines sites, the landsystems were assigned as part of this study as we are not aware of any published landsystem classification that currently exists. For the Nepal sites an existing landsystem classification, developed by Carson et al. (1986, in Dijkshoorn and Huting, 2009), was used. The landsystem evaluation was supported through field observations, analysis of digital elevation models, searches of peer-reviewed literature and other relevant geoscience information resources (e.g. geological maps, hazard and risk information, post disaster surveys, information on local scientific actors) and inspection of aerial imagery in Google Earth.

Fieldwork was carried out in multidisciplinary teams supported by staff from the CARE country offices and their implementing partners who had been involved in responding to the disasters. The locally-based team members also provided significant interpreting and logistical support. In the field, we used a range of tools to investigate the recovery process. Working in a multidisciplinary way was central to our methodology since it afforded a more holistic view of self-recovery than might have been achieved with a single discipline approach (Twigg et al., 2017). Twigg et al. (2017) provide a detailed account of how the research questions and methodology were developed and further information is given by Schofield et al. (2019). In the field, a variety of tools were used to gather information. These included introductory meetings with the leaders of the communities we visited, semi-structured interviews and focus groups with people in the communities (who were identified in that initial meeting), timeline mapping, transect walks and building surveys. All of these were chances to find out how the physical environment had affected (and was continuing to affect) people's self-recovery. Transect walks (often guided by a local social mobiliser or other community members) provided an opportunity for the whole team to learn about people's experiences of the disaster and subsequent recovery, their knowledge and understanding of the physical environment, 
and factors influencing the location of settlements. During the walks, community members pointed out areas that they perceived to be susceptible to different hazards or took us to sites of particular importance such as new landslides or efforts to manage environmental hazards (e.g. gabions on hillsides to protect communities from landslides and debris-laden overland flows). Focus group discussions took place in each of the 21 communities that were visited (nine in the Philippines and twelve in Nepal) and provided an opportunity to explore how the triggering event and subsequent environmental events were affecting recovery (e.g. by constructing hazard timelines). Semistructured interviews were carried out with a range of community members (including homeowners, builders and carpenters) to gain a perspective of the community's history, disaster experiences and recovery pathways. The interview records were coded according to different research themes (e.g. environment, economic, agency); the records from the environment theme have informed the findings of this paper.

\section{Results: Landsystems and recovery observations \\ Typhoon Haiyan on Leyte (Philippines) \\ Hazard overview}

Leyte is dominated by a north-north-west to south-south-east orientated central volcanic chain, which is aligned along the trace of the Philippine Fault. On the north-eastern part of the island the volcanic mountains have fed a system of alluvial fans, through which drainage is directed eastwards towards the flat-lying coastal plains (See Fig. 1A, B for the communities visited, which are located in the landsystems in Table 1). The hills of Babatngon Range, located immediately to the west of Tacloban City, locally divert this drainage southward to form a wide floodplain along the Palo River. Tacloban City is located along a narrow section of coastal plain that lies between the eastern side of the Babatngon Range and San Pedro Bay. A prominent sand spit extends out from this coastline, enclosing the smaller Cancabato Bay, around which much of Tacloban has been developed. 

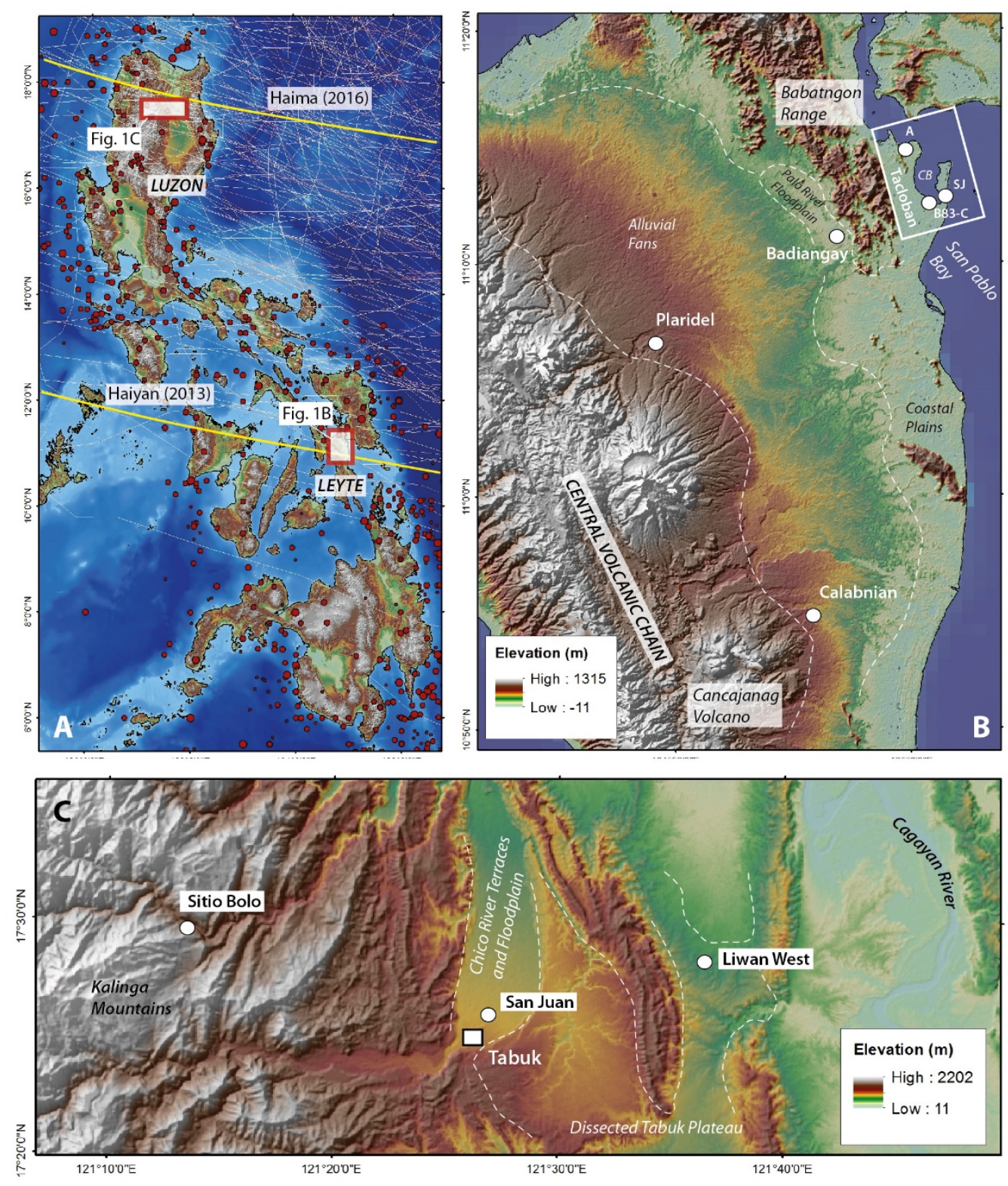

Figure 1. (A) Location of studied sites within the Philippines. See Table 1 for the information on landsystems. Yellow lines indicate the pathways of typhoons Haiyan and Haima. The thin lines make the tracks of historical tropical cyclones that occurred between 1969 and 2009, from the United Nations Global Assessment Report (GAR) Risk Data Platform (https://risk.preventionweb.net/capraviewer). Red circles represent earthquakes greater than 6.0 Mw that have occurred between 1619 and 2017 (B) Landscape context and locations of the communities visited on Leyte ( $\mathrm{A}=$ Anibong, $\mathrm{SJ}=$ San Juan, B83-C = Barangay 83-C, CB = Cancabato Bay). (C) Landscape context and location of the communities visited in Kalinga Province. The background elevation data is from NASA Shuttle Radar Topography Mission (SRTM) (NASA JPL, 2013). British Geological Survey (c) UKRI 2020. 


\begin{tabular}{|c|c|c|c|c|}
\hline Landsystem & $\begin{array}{c}\text { Communities } \\
\text { visited }\end{array}$ & Topography & Shallow geology & Disaster recovery barriers \\
\hline $\begin{array}{l}\text { Eastern Leyte } \\
\text { Alluvial fans }\end{array}$ & $\begin{array}{l}\text { Calabnian }[R] \text {, } \\
\text { Plaridel }[R]\end{array}$ & $\begin{array}{l}\text { Gentle surface } \\
\text { slope }\left(\sim 2^{\circ}\right) \text {, with } \\
\text { river terraces and } \\
\text { incised channels. }\end{array}$ & $\begin{array}{l}\text { Pliocene, Pleistocene, and } \\
\text { recent alluvial fan sands } \\
\text { (generally freely draining) in } \\
\text { excess of several tens of } \\
\text { meters thickness. Some } \\
\text { coarser and finer material } \\
\text { associated with localized } \\
\text { channels and narrow flood } \\
\text { plains. }\end{array}$ & $\begin{array}{l}\text { Long time scale required for crops to } \\
\text { recover (e.g. coconut trees); } \\
\text { significant groundwater lowering } \\
\text { during dry season and particularly } \\
2014-16 \mathrm{El} \text { Nino affecting crops and } \\
\text { livelihoods; short-lived flood events } \\
\text { that block bridges cutting off } \\
\text { community access. }\end{array}$ \\
\hline $\begin{array}{l}\text { Palo River } \\
\text { Flood Plain }\end{array}$ & Badiangay $[R]$ & $\begin{array}{l}\text { Very flat (average } \\
\text { slope }<0.2^{\circ} \text { ) }\end{array}$ & $\begin{array}{l}\text { Recent floodplain clayey and } \\
\text { silty soils; very poorly drained } \\
\text { with high groundwater table. }\end{array}$ & $\begin{array}{l}\text { Regular annual flooding. Difficulty } \\
\text { over ownership of decisions to add a } \\
2^{\text {nd }} \text { floor to escape regular floods; } \\
\text { Long time scale required for crops to } \\
\text { recover. }\end{array}$ \\
\hline $\begin{array}{l}\text { Tacloban } \\
\text { Coastal Plain }\end{array}$ & $\begin{array}{l}\text { Anibong }[U] \text {, } \\
\text { San Juan }[U], \\
\text { Brgy 83-C [U] }\end{array}$ & $\begin{array}{l}\text { Varied. Ranging } \\
\text { from flat sand spit a } \\
\text { few meters above } \\
\text { sea level, to small } \\
\text { hills (slope up to } 30 \\
{ }^{\circ} \text { ) adjacent to } \\
\text { coastline }\end{array}$ & $\begin{array}{l}\text { Mostly recent sand and gravel, } \\
\text { with some areas of clay and } \\
\text { silt, particularly around river } \\
\text { mouths. Isolated coastal hills } \\
\text { are composed of weathered } \\
\text { sedimentary bedrock. }\end{array}$ & $\begin{array}{l}\text { Limited space with many shelters } \\
\text { existing on hazard exposed sites; } \\
\text { river and tidal flooding mixing with } \\
\text { sewage; fear of the physical } \\
\text { environment due to specific disaster } \\
\text { memory; flood damage to wooden } \\
\text { housing materials; reduced } \\
\text { empowerment to strengthen existing } \\
\text { home due to planned relocation to } \\
\text { different physical environment. }\end{array}$ \\
\hline $\begin{array}{l}\text { Kalinga } \\
\text { Mountain } \\
\text { Slopes }\end{array}$ & Sitio Bolo [R] & $\begin{array}{l}\text { Bench on } \\
\text { mountainside with } \\
\text { steep slopes } \\
\text { (exceeding } 40^{\circ} \text { in } \\
\text { places) above and } \\
\text { below community }\end{array}$ & $\begin{array}{l}\text { Bedrock composed of } \\
\text { weathered sedimentary rock, } \\
\text { with a cover of colluvial soils. } \\
\text { Numerous landslide scars } \\
\text { visible in the landscape. }\end{array}$ & $\begin{array}{l}\text { Large number of landslides blocked } \\
\text { access road for weeks after the } \\
\text { typhoon; access - the community is } \\
\text { still a } 1 \mathrm{~km} \text { walk from the road; lack } \\
\text { of 'safe' space for new buildings in } \\
\text { community; ongoing concern about } \\
\text { landslides onto road. }\end{array}$ \\
\hline $\begin{array}{l}\text { Chico River } \\
\text { Terraces and } \\
\text { flood plain }\end{array}$ & San Juan $[R]$ & $\begin{array}{l}\text { Very gentle slope } \\
\left(0-2^{\circ}\right) \text {. Stepped river } \\
\text { terraces are } 5-10 \mathrm{~m} \\
\text { above floodplain; } \\
\text { abandoned } \\
\text { channels present on } \\
\text { floodplain }\end{array}$ & $\begin{array}{l}\text { Sandy loam soil overlying sand } \\
\text { alluvial sand and gravel. } \\
\text { Generally well draining. Water } \\
\text { table close to surface on } \\
\text { floodplain, but deeper on the } \\
\text { terraces. }\end{array}$ & $\begin{array}{l}\text { Already missed harvest due to } \\
\text { previous typhoon - Haima has added } \\
\text { to this situation furthering existing } \\
\text { debts; some houses continue to } \\
\text { flood; recent construction diverting } \\
\text { drainage and enhancing flood } \\
\text { impacts elsewhere. }\end{array}$ \\
\hline $\begin{array}{l}\text { Tabuk } \\
\text { plateau }\end{array}$ & $\begin{array}{l}\text { Liwan West } \\
\text { [R] }\end{array}$ & $\begin{array}{l}\text { Low and gently } \\
\text { undulating plateau, } \\
\text { with deeply incised } \\
\text { streams }\end{array}$ & $\begin{array}{l}\text { Dry silty fine sandy soil } \\
\text { overlying volcanic sourced } \\
\text { sedimentary rocks. } \\
\text { Groundwater table tens of } \\
\text { meters below surface }\end{array}$ & $\begin{array}{l}\text { Groundwater lowering during dry } \\
\text { season, difficulty with water supply; } \\
\text { uncertainty for crops due to } \\
\text { changing weather; insufficient funds } \\
\text { to transition to more drought } \\
\text { resistant crops; unable to pay debts } \\
\text { from destroyed rice field. }\end{array}$ \\
\hline
\end{tabular}

Table 1. Landsystems and their attributes for the Philippine case study, and the barriers to recovery barriers observed in each.

The island lies near the southern limit of the main tropical cyclone track that passes over the Philippines (Fig. 1A). Of the 99 tropical cyclones that entered the Philippine Area of Responsibility (PAR) between 2006 and 2016, only four passed directly over or to the south of Leyte (OCHA, 2016). However, statistical analysis using a longer-term data set has suggested that the number of tropical cyclones making landfall around Leyte has been steadily increasing over the past seven decades (Takagi and Esteban, 2016). These tropical cyclones generate high and damaging wind speeds that can also lead to storm surges in coastal areas and bring intense rainfall causing flooding and triggering landslides. 
As a whole, the island has relatively limited exposure to volcanic hazards. With the exception of Cabalian Volcano near the southern tip of the island, none of the volcanoes are classified as active (i.e. for some volcanoes there is evidence of Holocene eruptions (last 10,000 years) from either historical records and/or analysis of deposits, PHIVOLCS, 2008). However, the Cancajanag volcano has been classified as potentially active (PHIVOLCS, 2008; Eco et al., 2015). Seismic hazard is very high. According to the OCHA Regional Office for Asia Pacific, ground shaking intensities of IX-XII on the Modified Mercalli Intensity (MMI) Scale, have a return period of 225 years (OCHA Regional Office for Asia Pacific, 2011). This is ground shaking is strong enough to cause total destruction of all types of structures. The last significant earthquake to affect the area was on 6 July 2017 (M 6.5) to the north-north-east of Ormoc City. It caused heavy damage and the deaths of several people in the affected region (maximum intensity VII-VIII MMI, USGS Earthquake Catalog, accessed 2018).

\section{Eastern Leyte alluvial fans landsystem: Calabnian and Plaridel}

The inland rural communities of Calabnian ( $50 \mathrm{~m}$ above sea level) and Plaridel ( $130 \mathrm{~m}$ above sea level) represent communities in an alluvial fans landsystem. They occupy gently eastward sloping (approximately $2^{\circ}$ ) alluvial fan surfaces, characterised by a sandy loam surface overlying at least several tens of meters of well-draining sand (known by locals from water wells). The alluvial fan surfaces are generally inactive, and are incised by rivers that have cut down to their modern levels leaving terraces that stand above their relatively narrow floodplains. Plaridel occupies one such terrace, whereas Calabnian is located on ground that lies closer to the modern river level. Both communities are bounded to the north and south by rivers, which are passed by bridges along a single access road. Land use around the communities is predominantly cropland and coconut plantation. Maps produced by the Mine and Geosciences Bureau (MGB, 2015a,b) and the National Operational Assessment of Hazards (Project NOAH) suggest that Palridel has a low flood susceptibility, and that the Calabnian flood susceptibility is mostly low with some areas of high susceptibility. Calabnian is also in an area that is shown on maps to be prone to a lahar (a type of debris flow comprised of volcanic deposits) hazard from the potentially active Cancajanag Volcano on the volcanic hazard map (the READY Project, 2009).

Residents within these two inland communities reported that the main cause of damage was the intense winds associated with Typhoon Haiyan. However, the main challenges to their recovery are linked to water availability and failure of crops. Typhoon Haiyan was followed by a strong El Niño event in 2015 and 2016, associated with reduced rainfall and long dry spells in the Philippines (FAO, 2017). Community members reported that during this spell, crops had failed (including crops from previous livelihood assistance programs) and grass lands died off, limiting the food available for their livestock. The highly permeable and sandy nature of the shallow geology combined with deeply incised rivers has made communities in this landsystem susceptible to groundwater fluctuations. This has enhanced the effects of the dry spell, and local people reported that several water pumps dried up and there was little water flowing in the rivers. The combination of drought-related crop

damage with the already-damaged coconut and banana trees from the typhoon winds (these take 12 years to recover), has caused significant interruption to food availability and financial barriers to recovery. During one focus group, participants expressed that "we cannot prepare for drought" and felt concerned as they were unsure how to adapt to the recent climate variability that they had experienced. In one focus group the community members voiced that they needed training in how to adapt, grow, and market crops in a more variable climate.

Another barrier is related to access to more remote rural communities. Although the communities on the alluvial fans are generally located on elevated terraces that are not flood prone, the bridges that pass rivers to access the communities are vulnerable. One local resident reported during the 
transect walk that "even though we are safe when the rivers are high, we still get trapped" referring to surrounding areas where transport and access to services is blocked by high river levels.

\section{Palo River floodplain landsystem: Badiangay}

Badiangay lies at approximately $10 \mathrm{~m}$ above sea level at a distance of $7.5 \mathrm{~km}$ from the coast, and is located on flat (slope of $<0.2^{\circ}$ ), low-lying ground that forms the flood plain of the Palo River. The soil is naturally clayey and not well draining. As a result, the surrounding landscape is predominantly used for rice fields with some coconut plantations. Published flood hazard maps (MGB, 2015; NOAH, 2018) indicate that the community occupies areas of moderate and high flood susceptibility, which is in agreement with a map produced by the community itself (Stephenson et al., 2018).

The primary cause of damage in this community during Typhoon Haiyan was the intense wind speeds that destroyed 125 out of 128 houses (Fig. 2A, B). Flooding also impacted the community, with residents reporting that water levels reached "knee to waist depth". Flooding was a common theme in the focus group discussion about recovery, as might be expected in a community located within the floodplain landsystem: "we experience flooding every year... water can stay high for several days". The extent of flooding during Typhoon Hagupit (associated with lower wind speeds than Typhoon Haiyan, but high total rainfall), which occurred one year after Typhoon Haiyan, illustrates this kind of impact on the community (Fig. 2C). Repeated flooding causes rot and termite infestation, both of which increase the vulnerability of wooden housing.

As part of their ambitions for recovery, several local people in the focus group voiced a desire to add a second floor to their homes, for example: "Last December [2016] flooding reached head height, so I want a two-storey house"; and "I want a $2^{\text {nd }}$ floor so that if there is flood, we can just go upstairs instead of evacuating". Although such modifications could assist with adaptation to the regular flood hazard, community members were also aware that a $2^{\text {nd }}$ floor on a lightweight wooden home would be more vulnerable to intense winds. This gives an example of dilemmas faced by local residents when recovering in a multi-hazard environment.

Tacloban coastal plain landsystem: Anibong (Brgy 67), San Juan (Brgy 88), and Brgy 83-C The coastal plain around Tacloban is a complex environment that combines coastal headlands, partially enclosed bays and a coastal spit, and includes the mouths of the Mangonbangon and Burayan rivers. The coastline backs onto relatively flat ground, much of which lies below $5 \mathrm{~m}$ above sea level, before steep slopes (in places up to $50^{\circ}$ ) lead to hills of the Babatngon range (formed by the Tacloban Ophiolite Complex). Space is particularly limited in barangays ${ }^{5}$ such as Anibong (Brgy 67 ) in the northern part Tacloban city, where the coastline, the Mangonbangon River, and a group of

\footnotetext{
${ }^{5} \mathrm{Brgy}$; the smallest administrative division in the Philippines
} 

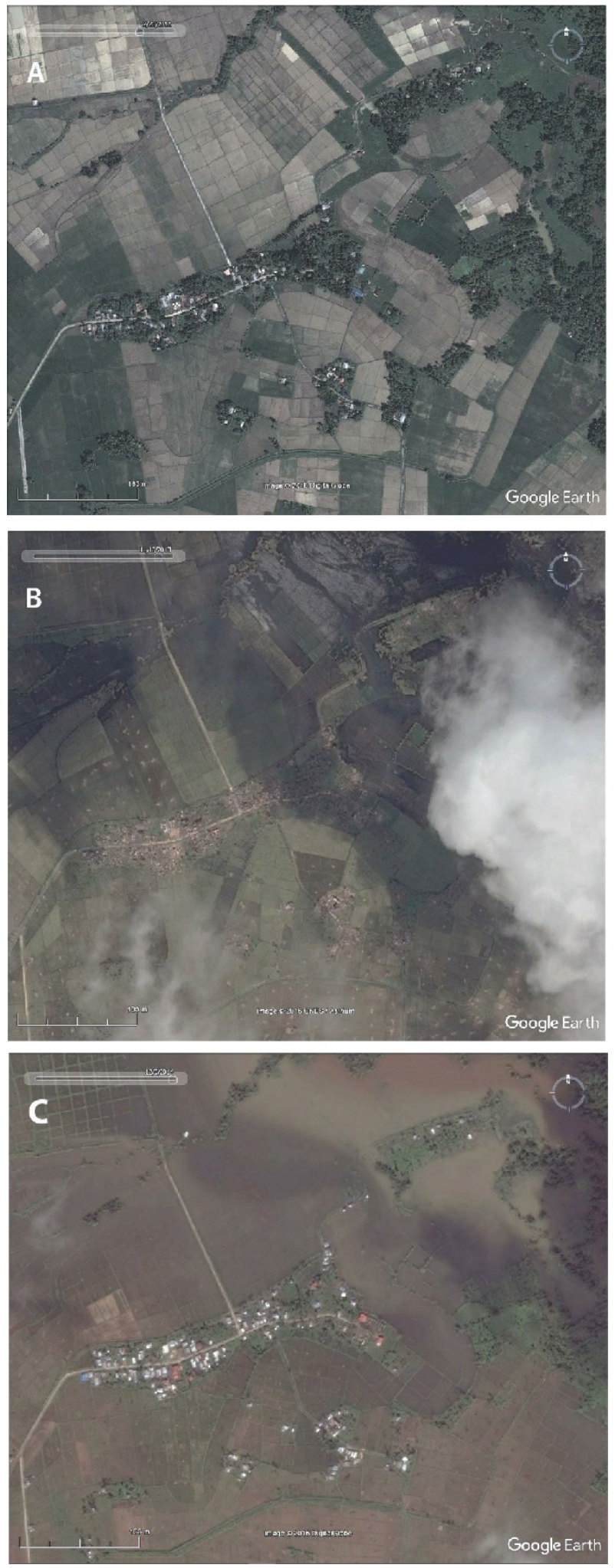

Figure 2. (A) DigitalGlobe image (23 February 2012) courtesy of Google Earth showing the community of Badiangay prior to Typhoon Haiyan. (B) CNES/Airbus image (13 November 2013) courtesy of Google Earth showing the severe wind damage to the community five days after Typhoon Haiyan passed through. (C) DigitalGlobe image (9 December 2014) courtesy of Google Earth, showing the extent of flooding around reconstructed houses following heavy rainfall associated with Typhoon Hagupit. British Geological Survey (c) UKRI 2020. 
outlying hills with slopes up to $30^{\circ}$ (composed of weathered sedimentary rocks) all occur in very close proximity (Fig. 3). As a result, a number of shelters encroach out into the sea. At the opposite, south-eastern side of Tacloban City, the barangay of San Juan (Brgy 88) is located on a coastal sand spit where the ground surface rarely rises above a few meters above sea level, and everywhere is within $500 \mathrm{~m}$ of the coastline. Both Anibong and San Juan are located in areas where published maps indicate a high storm surge hazard level - and are now classified as no-dwelling zones (Ong et al., 2016; NOAH, 2018). Anibong also includes areas exposed to flood hazard from the Mangonbangon River and a landslide hazard from the hills that the community backs onto.

Barangay $83-\mathrm{C}$ is located along the banks and close to the mouth of the Burayan River, and is also exposed to river flooding.

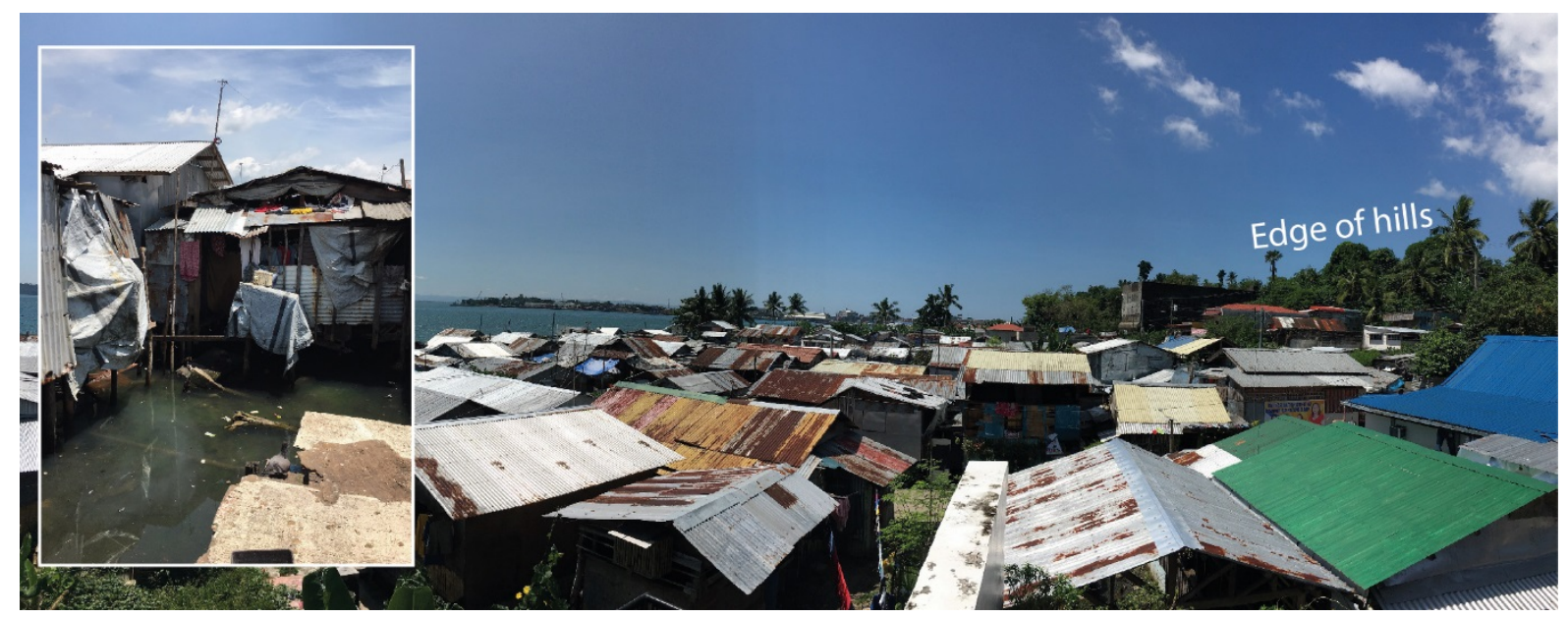

Figure 3. Photograph illustrating context for the community of Anibong, Tacloban. Closely spaced houses are located between the sea and a group of outlying hills. Inset: Shelters encroaching into the sea and are vulnerable to frequent low severity tidal flooding. British Geological Survey (c) UKRI 2020. 
The cause of much of the damage and devastation in Tacloban was the powerful storm surge that accompanied Typhoon Haiyan (Lagmay et al. 2015). Inundation heights were in excess of $5 \mathrm{~m}$ in many parts of coastal Tacloban and northern neighbourhoods within the city were damaged by ships and containers that were washed ashore (Mas et al., 2015; Makami et al., 2016). Wind damage was also severe and slope failures affected the isolated hills behind the community of Anibong (Mas et al., 2015). Housing recovery in these areas has largely been dominated by relocation programmes and classification of the severely affected neighbourhoods as 'no-dwelling zones' due to their location in areas with high storm surge hazard levels. Discussion of recovery in the relocation sites has been published elsewhere (e.g. Maly, 2018), and is beyond the scope of this paper. However, the relocation process is taking a number of years and many residents still remain in their original neighbourhoods, if only on a 'part time' basis.

Many participants indicated that they were still traumatised by the disaster, and that for some this has led to a fear of the environment that they live in. For example:

"I'm scared of the sea. Given a signal 1 storm I'm already scared I can't sleep. I'm traumatized by the sea. Years back during heavy rain my children would cry. They were scared"

(Female interviewee, 37, Anibong)

and

"It is still not safe here. During Urduja [Tropical Storm Kai-tak (2017)], we evacuated because we were scared of the sea. Also, it is not safe because the houses here are near the sea. There are container vans near the port and it could be washed out."

(Female interviewee, 66 Anibong)

These concerns were primarily focused around the storm surge and people's proximity to the sea. However, some local people in Anibong were also concerned about the hillslopes:

"We are worried because we heard that there will be another typhoon. That is why we always listen to radio so we could prepare especially that the hill causes landslide".

(Female interviewee, 53 Anibong)

Another strong theme that came through in discussions with local residents related to problems encountered as a result of continued seasonal flooding, particularly in the community near the mouth of the Burayan River. These concerns relate both to the weakening of houses and to health implications. For example:

"If it rains, the area gets flooded. The plywood rots because of the rain. Some materials we replace. Another thing is that when it floods, the garbage also comes up. We really need to clean then the mosquito come"

(Female interviewee, 28, Barangay 83-C)

and 
"Here is prone to flooding. It is a problem because the water is not clean. It comes from the drainage system. Waste waters from other houses. During floods people get chikungunya ${ }^{6}$ and skin disease. The floodwater enters our house when it rains. It happens during rainy season. Especially when the tide mixes with drainage. The sea is close".

(Female interviewee, 63, Barangay 83-C)

In communities targeted for relocation, some local people voiced a reluctance to try to improve their current homes because of their planned relocation, despite it now being five years since the disaster:

"We did not consider the roof and bracing because we thought we were going to be moved soon".

(Male interviewee, 42, Anibong)

This has contributed to a sense of loss of control and fear of the physical environment in these locations.

\section{Typhoon Haima in Kalinga Province, Northern Luzon}

Hazard overview

Kalinga Province is located in northern Luzon and spans steep mountainous terrain (up to $2500 \mathrm{~m}$ ) in the west, to the low, dissected and undulating Tabuk Plateau and river basins in the east (Fig. 1C). The Chico River is the main drainage that flows through the area; it has deposited a large alluvial fan and river terrace and flood plain system where it emerges from the mountains onto the lower relief terrain. Tabuk (population 110,000) is the capital of the province and is mostly built upon the alluvial fan where the Chico River exits the mountains.

Kalinga Province is located at a latitude frequently crossed by tropical cyclones (Fig. 1); these are commonly associated with landslides in the mountainous areas and river flooding. Model results available from the United Nations Global Assessment Report (GAR) Risk Data Platform (https://risk.preventionweb.net/capraviewer) suggest that wind speeds associated with a 50-year return period cyclone over the Kalinga Province range from 250 to $260 \mathrm{~m} / \mathrm{s}$. The nearest active volcano is Cagua (latest activity 1907), located approximately $100 \mathrm{~km}$ to the northeast of the province (NOAH, 2018). Seismic hazard in Kalinga Province is relatively high. Ground shaking intensity of VIII MMI is estimated to have a return period of 225 years (UNOCHA, 2011). This level of shaking can cause slight damage in specially designed structures, considerable damage in ordinary substantial buildings and severe damage to poorly built structures.

\section{Kalinga Mountain Slopes landsystem: Sitio Bolo}

Sitio Bolo is located on the northern slopes of Mount Balantay (Fig. 4A). The centre of the community lies at an elevation of $540 \mathrm{~m}$, and the steep slopes above rise to an elevation of more than $1000 \mathrm{~m}$. The main community and the surrounding rice fields are clustered around the gently sloping surface (generally less than $15^{\circ}$ ) on a bench that protrudes from the mountainside. However, the slopes above and below the community are considerably steeper, exceeding $40^{\circ}$ in places. The bedrock in the vicinity of the community is sedimentary (comprising greywackes, shales, limestones, and conglomerates). In numerous places, these rocks are weathered at the surface, and are covered locally by colluvial soils (loose, unconsolidated sediments deposited at the base of

\footnotetext{
${ }^{6}$ Chikungunya is a virus spread by mosquitos that can cause symptoms including fever, joint pain, headache, muscle pain, joint swelling or rash (Centre for Disease Control and Prevention, 2019)
} 
hillslopes). Sitio Bolo is accessed by a steep one-kilometre walk downhill from the only road in the valley. From the road, travel down to the closest town, Tabuk, requires a 2-3 hour drive. The 1:10,000 scale Mines and Geosciences Bureau (MGB) landslide and flood hazard map indicates that Sitio Bolo occupies an area of high susceptibility to landslides.

In the mountain slope community some building damage was caused by high winds, but this was generally limited to roof damage. Numerous landslides blocked the access road (e.g. Fig. 4B) and affected the community's irrigation system, and one house in a neighbouring community was buried. River bank erosion at the valley base also destroyed a bridge preventing access to fields on the opposite side of the valley.

In general, the community recovered quickly following Typhoon Haima. They pooled their resources to repair the irrigation system, preventing longer-term damage to rice fields, and worked together to repair the local farm-to-market road and each other's houses. However, the time taken to make the road to the main town (Tabuk) passable (15 days) affected some of the repair and reconstruction efforts. During the field visit, which took place six months after the typhoon, the road was still partially blocked by debris from a large number of landslides (e.g. Fig. 4C). The vulnerability of the road to future events was voiced as a concern by members of the community in the focus group discussion.
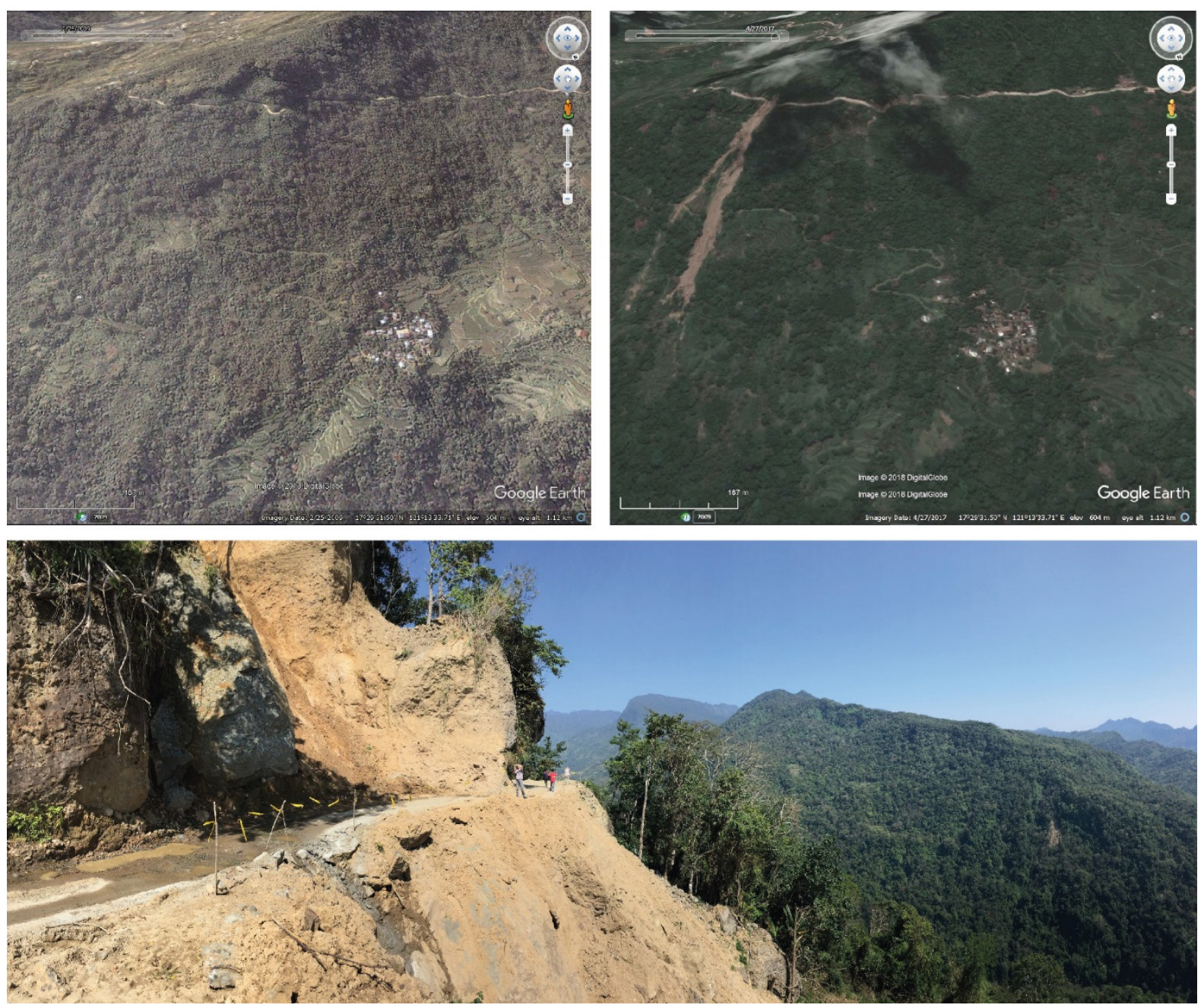
Figure 4. (A) Digital Globe Image (25 ${ }^{\text {th }}$ February, 2009) courtesy of Google Earth illustrating the context for the community at Sitio Bolo. (B) Digital Globe Image ( $5^{\text {th }}$ February 2017) courtesy of Google Earth showing the extent of a debris flow adjacent to the community, that was triggered by heavy rainfall during Typhoon Haima. (C) Photograph illustrating conditions on the only access road in March 2017, 6 months after the typhoon. A large landslide scar is clearly evident and unstable blocks remain above the road. Local people spoke of concerns about the continued threat of landslides here. British Geological Survey (c) UKRI 2020. 
The community has a strong environmental awareness, based on their observations, experience and ancestral knowledge. For example, in a focus group discussion around landslide hazards participants reported: "we don't go there - it's a dangerous site" and "we look for tension cracks" (to indicate instability). They have a community tree planting programme and forbid burning farming practices in the summer. However, focus group participants did voice ongoing concerns regarding a perceived increase in landslide activity, attributing this to changing weather patterns: "because of climate change - there's more water in the mountains". A consequence of their location within the mountain slope land system is that of limited space: the more gentle slopes are already occupied or used for agriculture, so new generations are having to build homes on the steeper slopes near the community margins. This was noted as a future concern by some community leaders.

\section{Chico River terraces and flood plain landsystem}

A number of 'puroks' (neighbourhoods) were visited in a community spread out across river terraces and the flood plain of the Chico River. Here, the land surface slopes very gently towards the northeast (approximately $0-2^{\circ}$ ), following the general direction of the Chico River. The surface is covered by a sandy loam soil, which overlies several tens of meters of sands and gravels deposited by the Chico River. Maps produced by the MGB (2015d) indicate that the different puroks have a low to high flood susceptibility, depending on their location on the river terraces or the floodplain. Those with the highest flood susceptibility are located very close to abandoned river channels. The surrounding land use is primarily cultivated (rice fields) mixed with grasslands.

The damage to this community during Typhoon Haima was primarily caused by wind on the terraces and by flooding in areas of lower elevation on the flood plain close to the river. In the flood-affected areas, local people reported that the water was "waist high" for three days. A large area of rice fields were covered by sand and gravel deposited during the river flooding.

As with other communities, the dry weather that accompanied the 2015-16 El Niño and preceded Typhoon Haima had caused initial difficulties for farming families: "Recovery is very far from my mind, I was struggling even before Lawin". A previous typhoon in 2015 - Typhoon Koppu (local name 'Lando') was also reported by local people to have damaged crops. As a result, some local people's debts have increased, further preventing their recovery:

"No one has been able to recover yet... when Lawin (Haima) happened, we were pushed further into hardship because we were already borrowing money before, and after we had to borrow more".

(Focus group participant, San Juan)

The impact of this is that some local people do not feel that they are equipped (either with the skills. resources or livelihoods) to adapt to the dynamic nature of the climate and environment: "To recover we need an alternative source of livelihood".

Parts of the community that are located close to the flood plain are also exposed to continued flooding: "My house has continued to flood". In order to recover, one focus group participant said that they need: "better drainage against flooding". Some of the local people also suggested that recent constructions have blocked some drainage pathways, which have increased the frequency and severity of flooding in their homes. This concern raised the issue of understanding upstream and downstream impacts of developments and interventions in river basins. 


\section{Dissected Tabuk Plateau landsystem}

The Tabuk Plateau community occupies a gently undulating surface (approximately $100 \mathrm{~m}$ above sea level), through which the main streams are deeply incised. The soil cover is a dry, silty, fine sand, which overlies rocks of the Awidon Mesa Formation (volcanic sourced sedimentary rocks). MGB (2015) and Project NOAH maps suggest that the community is not exposed to any significant flood or landslide hazard. The surrounding areas are mostly covered by grassland.

The damage to the community on the Tabuk Plateau was almost entirely caused by intense winds and a number of houses were completely destroyed. Like the communities of the Leyte alluvial fans landsystem, the key barriers to recovery are water availability, agricultural productivity and debt. The community was already severely affected by dry spells associated with the 2015-16 El Niño: "There is no certainty in the harvest, even without the typhoon". The incised, permeable nature of the geology on the plateau means that groundwater levels lie far below the surface. One community leader stated that the water table is approximately $25 \mathrm{~m}$ below the ground surface, and lowers by a further $8 \mathrm{~m}$ during the dry season. Water wells drilled into bedrock are vulnerable to fluctuations in the level of the water table and at the time of the field visit one well had dried up. Another wind-powered well (built by an NGO) was damaged and no longer worked.

These environmental conditions have had significant impacts on agricultural productivity, causing debt and further impacting efforts to rebuild following the typhoon. Focus group participants explained that regular water shortages have caused them to delay the planting season (searching for other sources of livelihood during that time), and extend the growing season into cooler months, which affect crop yields. The community was very aware of changing weather patterns; however they indicated that they do not feel financially equipped to cope:

"Root crops and sugar cane are more drought resistant, but sugar cane takes years to grow so we would need to take credit first".

(Focus group participant, Liwan West)

\section{Gorkha Earthquake in Nepal}

\section{Hazard Overview}

Nepal is severely affected by geohazards. The country is highly seismically active due to its position in the collision zone between the Indian plate and Eurasian plate. It has a history of damaging earthquakes. The last great earthquake to affect the country before 2015 occurred in 1934 (8.2 Mw) and caused widespread destruction (Bilham et al., 2001; Sapkota et al., 2013). Besides earthquaketriggered landslides, other geohazards (e.g. landslides and flooding) are often triggered by hydrometeorological events associated with monsoon rainfall. In general, the occurrence and impact of landslides can be further exacerbated by a range of factors including population growth (rapid growth of small towns in rural areas is significantly increasing risk because many new constructions are vulnerable to earthquakes, e.g. Anhorn et al., 2015), land use change (deforestation), urbanisation, transport infrastructure development and the effects of a changing climate (Petley et al., 2007; Froude and Petley, 2018).

Throughout the area, the characteristics of the underlying geology strongly control slopes with gently undulating topography in the south and more steep and rocky terrain further north where the valleys are deep and steep-sided. In most places, many slopes have been terraced for agriculture, making use of superficial sedimentary deposits. These tend to be silts, clays and fine sands in the southern parts, becoming increasingly coarser grained (and better draining) towards the north. The mapping of co-seismic landslides following the Gorkha earthquake (e.g. Williams et al., 2018) 
indicated a different landscape response in areas of high mountainous relief and steep slopes in harder rocks, compared to more hilly landscapes formed in softer rocks.

In the mid-1980s the major landsystems, landforms and land units of Nepal were identified and mapped by Carson et al. (1986, in Dijkshoorn and Huting, 2009). The communities visited as part of this research are located in the following landsystems (numbered) and landforms (named) in the middle and high mountain regions of Nepal (see Table 2 and Figs. 5, 6).

\section{Landsystem 10 - Ancient lake and river terraces.}

In this landsystem, the areas of Salyantar and Bhaktapur (Figs. 5, 6) were visited. Salyantar forms a large agricultural platform along a well-defined river terrace at elevations between 580 and $640 \mathrm{~m}$. The communities on the river terrace are accessed by roads that cut along steep escarpments that have formed at the edge of the fluvial deposits and in the underlying bedrock (Fig. 7A). These roads are highly susceptible to slope instability processes. The communities themselves, which are located on top of the terrace surface, are less susceptible to geohazards. However, recent persisting dry spells have affected crops and access to safe water (Paudyal et al., 2015). The old city of Bhaktapur (elevation approximately $1335 \mathrm{~m}$ ) is positioned approximately $13 \mathrm{~km}$ from Kathmandu City in the eastern part of the major intermontane basin that makes up the Kathmandu Valley. The sediments underpinning the old city centre of Bhaktapur are dominated by clays, silts, and fine sands deposited in the former lake basin upon which most of Kathmandu is now built. The terrain surrounding Bhaktapur was traditionally dominated by agriculture and local industrial developments, mainly in the form of brickyards. 

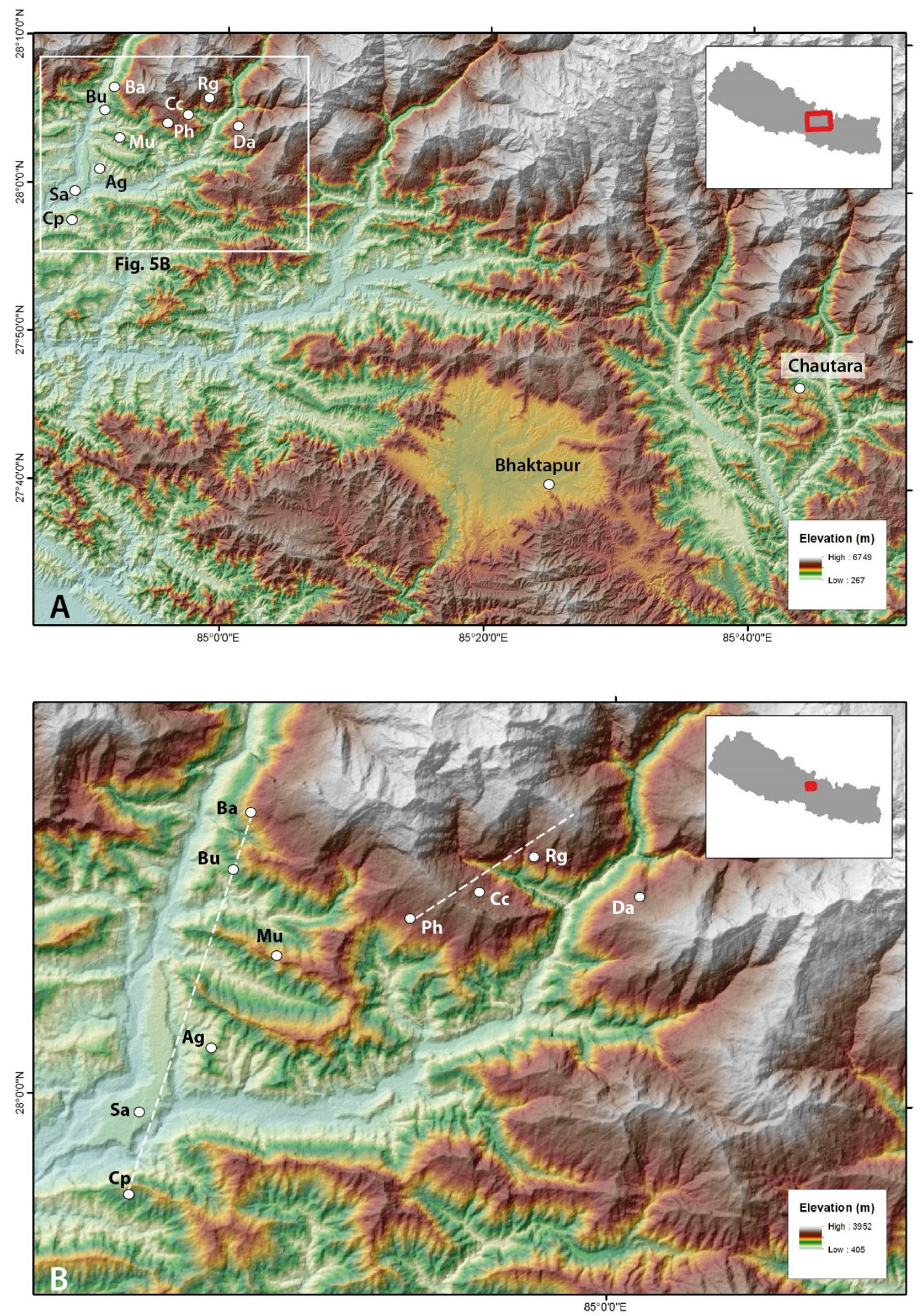

Figure 5. (A) Landscape context and location of communities visited in Nepal. (B) Detail of topographic context for the sites visited in Dhading. The dashed white lines indicate the lines of section shown in Figure 6. In both A and B: Cp - Chainpur; Sa - Salyantar; Ag - Aginchowk; Mu - Mulpani; Bu - Budhatum; Ba - Baseri; Ph - Phulkarka; Cc - Chimchock; Rg - Rigau; Da - Darkha. The background elevation data is from NASA Shuttle 
Radar Topography Mission (SRTM) (NASA JPL, 2013). The cross sections from Chainpur-Baseri and Phulkarka to Rigau are shown in Figure 6.

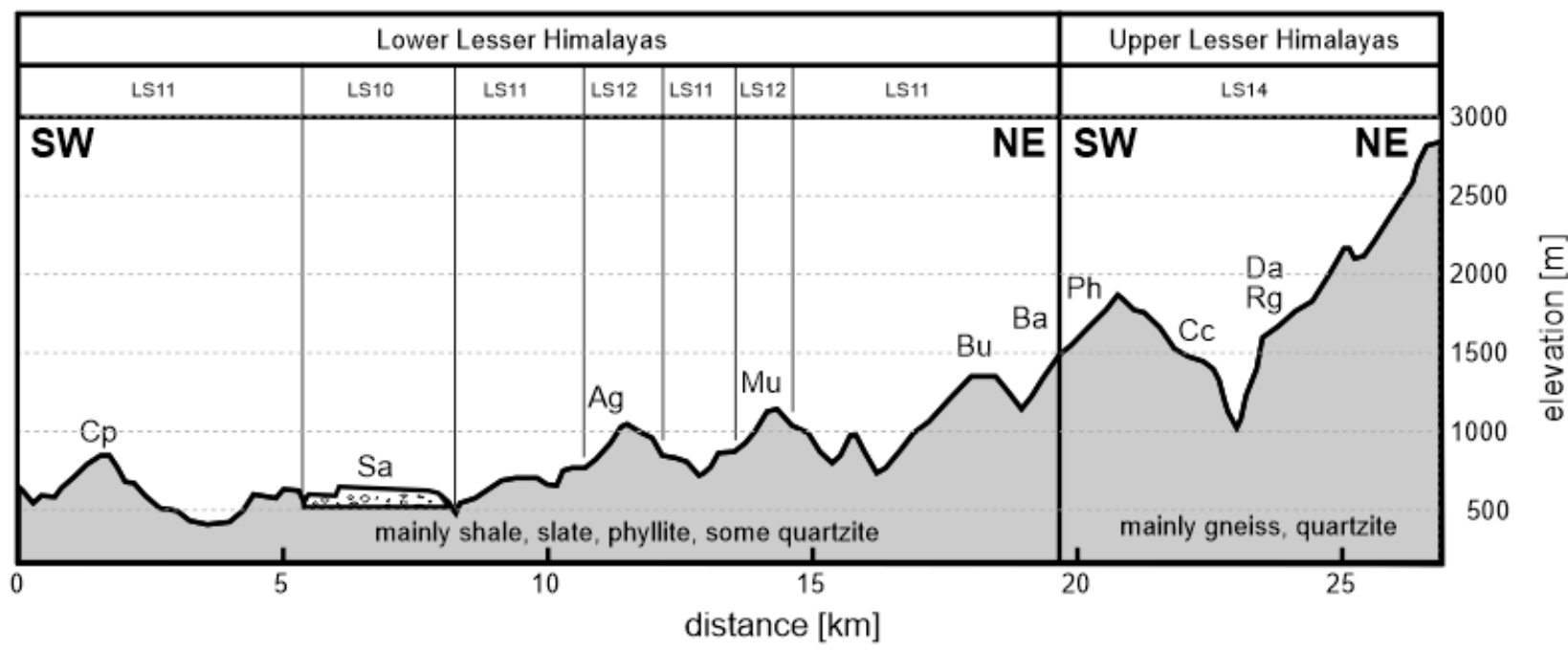

Figure 6. A schematic section through the Lesser Himalayas showing the position of the communities visited in Dhading. Cp - Chainpur; Sa - Salyantar; Ag - Aginchowk; Mu - Mulpani; Bu - Budhatum; Ba - Baseri; Ph Phulkarka; Cc - Chimchock; Rg - Rigau; Da - Darkha. There is a section offset between Baseri and Phulkarka (see Figure 5). The fill at Salyantar indicates the large terrace comprising ancient sediments of substantial thickness. See also Table 2 for a description of the landsystems (LS10, 11, 12, 14; cf. Carson et al., 1986 in Dijkshoorn and Huting, 2009).

Following the 2015 earthquake, four sets of landslides were observed along the Salyantar terrace edges affecting the main road between Salyantar and Arughat over long stretches ranging from $50 \mathrm{~m}$ to more than $200 \mathrm{~m}$. According to local people, these caused problems with access. The participants in one focus group spoke about how people gathered to create chains to carry materials in on foot because there was no functioning road network. The roads that did exist were damaged by the earthquake and required extensive repair work. They were also more susceptible to further disruption during subsequent monsoons because the terrace slopes had been weakened by the earthquake, leading to landslides at relatively low-intensity rainfall (compared to pre-earthquake conditions).

Access-related barriers to recovery were also apparent in Bhaktapur where unblocking roads made impassable by rubble and landslides was a major task for the people we interviewed. Restoring access often took at least several months and so delayed rebuilding, as did having to transport materials by hand. For example:

"Before that, it was blocked with debris and mud so the tractors couldn't get through. We had to carry the bricks and the cement".

(Interviewee, Bhaktapur)

The situation was made worse by labour shortages (e.g. as a result of people, particularly young men, travelling overseas to work), and many people had to make choices about what tasks to prioritise (e.g. farming activities). Clearing roads was also associated with its own costs on top of those for reconstruction: 
"First I had to remove the mud and debris from the construction site. This created 160 truck loads. One and a half lakh [150,000 Nepalese Rupees] for just one truck load"

(Male interviewee, 50, Bhaktapur)

\begin{tabular}{|c|c|c|c|c|}
\hline $\begin{array}{l}\text { Landsystem, } \\
\text { landform, } \\
\text { (cf. Carson et } \\
\text { al., 1986) }\end{array}$ & $\begin{array}{l}\text { Communities visited } \\
\text { [Rural/Urban, } \\
\text { elevation] }\end{array}$ & Topography & $\begin{array}{l}\text { Shallow geology; dominant } \\
\text { lithology (Dijkshoorn and } \\
\text { Huting, 2009) }\end{array}$ & Disaster recovery barriers \\
\hline $\begin{array}{l}10 \\
\text { Ancient lake } \\
\text { and river } \\
\text { terraces }\end{array}$ & $\begin{array}{l}\text { non-dissected fluvial } \\
\text { terrace/fan landform } \\
\text { Salyantar [R, 630m] } \\
\\
\text { terrace in fluvio- } \\
\text { lacustrine deposits of } \\
\text { Kathmandu Basin } \\
\text { Bhaktapur [U, 1335m] }\end{array}$ & $\begin{array}{l}\text { very gentle slope } \\
\left(0-2^{\circ}, \text { occasionally }\right. \\
\left.\text { up to } 10^{\circ}\right) \text {. Large } \\
\text { palaeo-fan/terrace } \\
\text { landform some } \\
200 \mathrm{~m} \text { above } \\
\text { current river-level. } \\
\text { Small escarpments } \\
(\sim 20 \mathrm{~m}) \\
\text { demarcating minor } \\
\text { terrace levels } \\
\text { Very gentle slope } \\
\left(0-2^{\circ}\right) \text {. Dominant } \\
\text { fluvial terrace } \\
\text { landform formed } \\
\text { in lacustrine } \\
\text { sediment } \\
\text { sequences }\end{array}$ & $\begin{array}{l}\text { complex sequences of } \\
\text { lacustrine and fluvial } \\
\text { deposits along eastern } \\
\text { margins of Kathmandu basin. } \\
\text { Mainly comprising fine } \\
\text { sands, silts and clays. }\end{array}$ & $\begin{array}{l}\text { Potential for liquefaction of } \\
\text { saturated fine-grained sediments. } \\
\text { This can be accompanied by } \\
\text { formation of large tension cracks } \\
\text { in the land surface. Lithological } \\
\text { amplification of seismic waves } \\
\text { can result in disproportionate } \\
\text { stress on construction. }\end{array}$ \\
\hline $\begin{array}{l}11 \\
\text { Moderate to } \\
\text { steep sloping } \\
\text { mountainous } \\
\text { terrain }\end{array}$ & $\begin{array}{l}\text { mid-slope locations } \\
\text { Phulkarka }[R, 1400 \mathrm{~m}] \\
\text { Budhatum }[R, 920 \mathrm{~m}] \\
\text { Baseri }[R, 1250 \mathrm{~m}] \\
\\
\text { ridge location } \\
\text { Chainpur }[\mathbf{R}, 1100 \mathrm{~m}] \\
\text { Chautara }[\mathbf{U}, 1450 \mathrm{~m}]\end{array}$ & $\begin{array}{l}\text { Slopes typically } 15- \\
30^{\circ} \\
\text { Few cliffs and } \\
\text { escarpments } \\
\text { steeper than } 50^{\circ} \\
\text { Significant upslope } \\
\text { catchment. }\end{array}$ & $\begin{array}{l}\text { Relatively soft rocks } \\
\text { comprising shale, slate, } \\
\text { phyllite, with thin cover of } \\
\text { regolith/slope deposits }\end{array}$ & $\begin{array}{l}\text { Regular annual flooding. Slope } \\
\text { instability in thin slope cover } \\
\text { materials. Heightened risk at } \\
\text { confluence of stream channels } \\
\text { draining denuded slopes. } \\
\text { Vulnerable transport } \\
\text { infrastructure routes often } \\
\text { exacerbate susceptibility to } \\
\text { geohazards and functionality is } \\
\text { frequently disrupted due to road } \\
\text { deformation/landslides. Difficulty } \\
\text { with water supply due to } \\
\text { changed spring locations/water } \\
\text { quality }\end{array}$ \\
\hline $\begin{array}{l}12 \\
\text { Steep to very } \\
\text { steep slope } \\
\text { mountainous } \\
\text { terrain }\end{array}$ & $\begin{array}{l}\text { ridge locations } \\
\text { Aginchowk }[R, 875 \mathrm{~m}] \\
\text { Mulpani }[\mathbf{R}, 1200 \mathrm{~m}]\end{array}$ & $\begin{array}{l}\text { Long, continuous } \\
\text { ridges, often } \\
\text { enabling transport } \\
\text { routes. Gently } \\
\text { sloping }\left(5-15^{\circ}\right) \text { and } \\
\text { bounded by } \\
\text { steeper slopes } \\
\text { (often }>25^{\circ} \text { ). }\end{array}$ & $\begin{array}{l}\text { Relatively hard rocks } \\
\text { comprising schist, gneiss and } \\
\text { quartzite, with thin cover of } \\
\text { loamy regolith/slope } \\
\text { deposits. Often evidence of } \\
\text { major landsliding along } \\
\text { ridges (e.g. Chainpur, } \\
\text { Mulpani) }\end{array}$ & $\begin{array}{l}\text { Rock falls from exposed, } \\
\text { weakened cliffs. Large landslides } \\
\text { with long runouts. Particularly } \\
\text { vulnerable transport } \\
\text { infrastructure routes that are } \\
\text { hard to maintain and are } \\
\text { frequently disrupted due to road } \\
\text { deformation/landslides. Difficulty } \\
\text { with water supply due to } \\
\text { changed spring locations/water } \\
\text { quality }\end{array}$ \\
\hline $\begin{array}{l}14 \\
\text { Past } \\
\text { glaciated } \\
\text { mountainous } \\
\text { terrain, } \\
\text { moderate to } \\
\text { steep slopes }\end{array}$ & $\begin{array}{l}\text { valley shoulder } \\
\text { location } \\
\text { Chimchok }[\mathbf{R}, 1525 \mathrm{~m}]\end{array}$ & $\begin{array}{l}\text { relatively gently } \\
\text { sloping terrain (10- } \\
\left.20^{\circ}\right) \text { bounded by } \\
\text { steeper slopes } \\
\left(>45^{\circ}\right) \text { both above } \\
\text { and below. }\end{array}$ & $\begin{array}{l}\text { Relatively hard rocks } \\
\text { comprising schist, gneiss and } \\
\text { quartzite, with thin cover of } \\
\text { loamy regolith, coarse slope } \\
\text { deposits or till. } \\
\text { Evidence of palaeo-rockfalls } \\
\text { embedded in slope deposits. }\end{array}$ & $\begin{array}{l}\text { Potential risk from long runout } \\
\text { landslides and rockfalls triggered } \\
\text { in upper slopes. } \\
\text { Vulnerable transport } \\
\text { infrastructure routes often } \\
\text { exacerbate susceptibility to } \\
\text { geohazards and functionality is }\end{array}$ \\
\hline
\end{tabular}




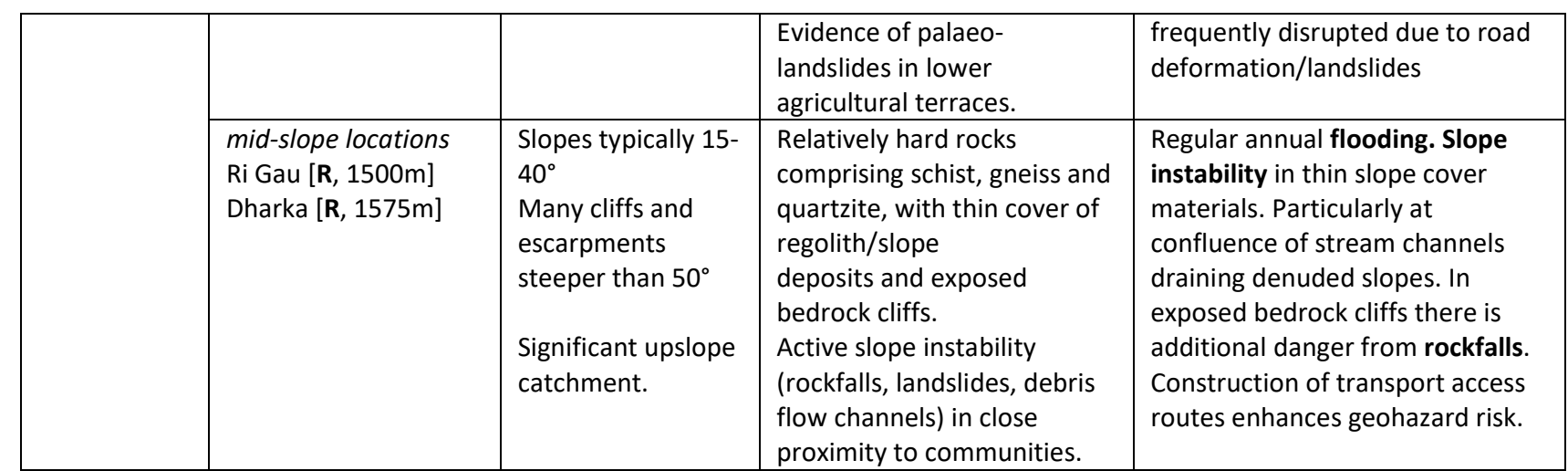

Table 2. Landsystems and their attributes for the Nepal case study, and the barriers to recovery observed in each.

Water availability was also reported by focus group participants to be a significant challenge affecting their recovery. One group (in Salyantar) reported that after the earthquake, a main source of water dried up and that there was a shortage of water for consumption and for irrigation (with further impacts for livelihoods within this agricultural setting). Building in Nepal is seasonal and strongly dependent on the availability of water, for example one interviewee reported:

"You can't build in the monsoon. You can't do things like the foundations but then you do need water later on".

(Interviewee, Bhaktapur)

The clayey and silty nature of the sediments under Bhaktapur make foundation excavation particularly challenging in wet conditions (Fig 7B). Another interviewee in Bhaktapur also described how the occurrence of dry spells can have an impact on rebuilding when mixing mortar: "Water is scarce here but it is important for the building" and people had to buy water from tankers to use in housing reconstruction, which increased the cost of rebuilding. The limited weather-controlled 'windows' for different building stages compounded delays caused by blocked roads and access difficulties, further slowing down peoples' recovery.

\section{Landsystems 11 and 12 - Moderate to very steep sloping mountainous terrain}

In this landsystem we visited communities located in two major land units: mid-slope and along ridges. The mid-slope communities are the rural communities of Phulkarka (elevation 1400m), Budhatum $(920 \mathrm{~m})$, Baseri $(1250 \mathrm{~m})$, and Aginchowk $(875 \mathrm{~m})$. The ridge top communities are the rural villages of Chainpur (1100 $\mathrm{m}$ ) and Mulpani $(1200 \mathrm{~m})$, and the more urban centre of Chautara (1450 m) (Fig. 5). The effects of the earthquake were particularly severe on the ridge top locations where topographic amplification may have enhanced the intensity of ground shaking (Wang et al., 2016; Sharma et al., 2017). In Mulpani the shaking resulted in almost $100 \%$ of the houses being destroyed.

The monsoon has had a significant impact on recovery in all communities in this landsystem. In Mulpani, residents rely on building materials from Salyantar; however, the access road is only passable for six months of the year due to the monsoon. Similarly in Baseri, which is accessed by a small unpaved road, local people indicated that access routes became impassable during the monsoon due to unstable slopes. In Chainpur people reported that the monsoon causes roads to become too muddy or blocked by debris for them to be used to transport materials. Local people in one focus group spoke about how trucks have to carry less material when roads become damaged by the monsoon. The result is that rebuilding costs increase because the price for each truck journey remains the same but the number of loads required increases. 

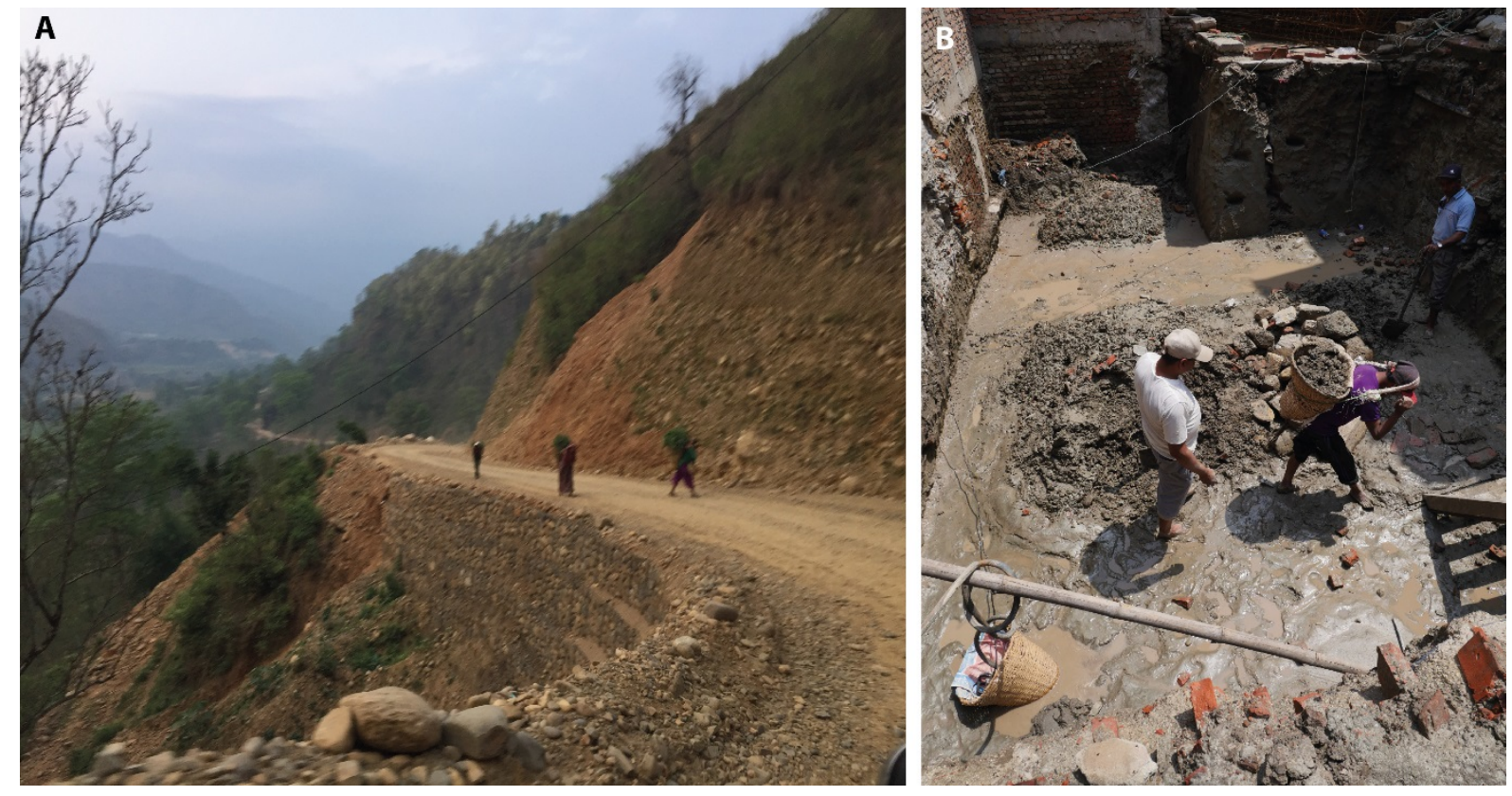

Figure 7. (A) The road that accesses communities on the Salyantar terrace is cut into a steep escarpment that is vulnerable to instability during monsoon rains. (B) Excavation in silts and fine sands with a sump pump, for building foundations in Bhaktapur in April 2018. Evidence for liquefaction below the feet of the construction workers. Local people reported that this stage of reconstruction is not possible during the monsoon.

In Phulkarka people also spoke about continued building damage caused by the monsoon. Part of the community is positioned in a small area between the confluence of two stream channels (Fig. 8). During the monsoon, the steep catchment slopes above this confluence supply rapid, high-discharge river flows that spill over into the community causing debris flow and flood damage to houses. The stream channels on either side of the community are unstable and subject to erosion, and gabion structures have been created in an attempt to control flow and stabilise channel banks (Fig. 8B). The community also reported a long-term battle with slope instability that they tried to address, without much success, through planting trees. The continuing instability in the landscape was expressed as a key concern in the community focus group:

"We still feel as though this area is prone to earthquakes and landslides are a risk here. If the government could do an assessment and put up retaining walls and give us some information on the stability of the area - that would be really important to us."

(Focus group, Phulkarka)

In addition to damaging access roads (through rainfall triggered landslides) and housing, the monsoon was reported to have had a direct impact on livelihood activities. In Chainpur, the early arrival of pre-monsoon rains damaged fields immediately after the earthquake:

"The earthquake destroyed our houses where we stored our harvest. Our fields with newly planted seedlings cracked and then washed away during the rains that followed the earthquake. We lost both our reserves and our planned future."

(Focus group, Chainpur)

Water supply during the drier winter season was also reported as a challenge to recovering communities. This was particularly evident in discussion with local people on the ridge top communities, which are generally built above natural spring lines. In Mulpani, people reported that 
they have to walk for 45 minutes to access water during the winter. In the focus groups, community members also indicated that they had problems with taps and pipes, and that they did not store water. In Chautara (Fig. 9), people rebuilding their homes spoke of a need for a more regular water supply to assist with rebuilding. At the time of the field visit, one interviewee explained that she has access to a water supply for one hour every three days. In Chainpur and Budhatum (one of the slope communities), focus groups reported that following the earthquake "the waters have disappeared into the ground", and indicated that they had not been able to grow fruit. This observation may be the result of altered fracture pathways in the bedrock (as a result of the earthquake) affecting traditional natural water supply points.
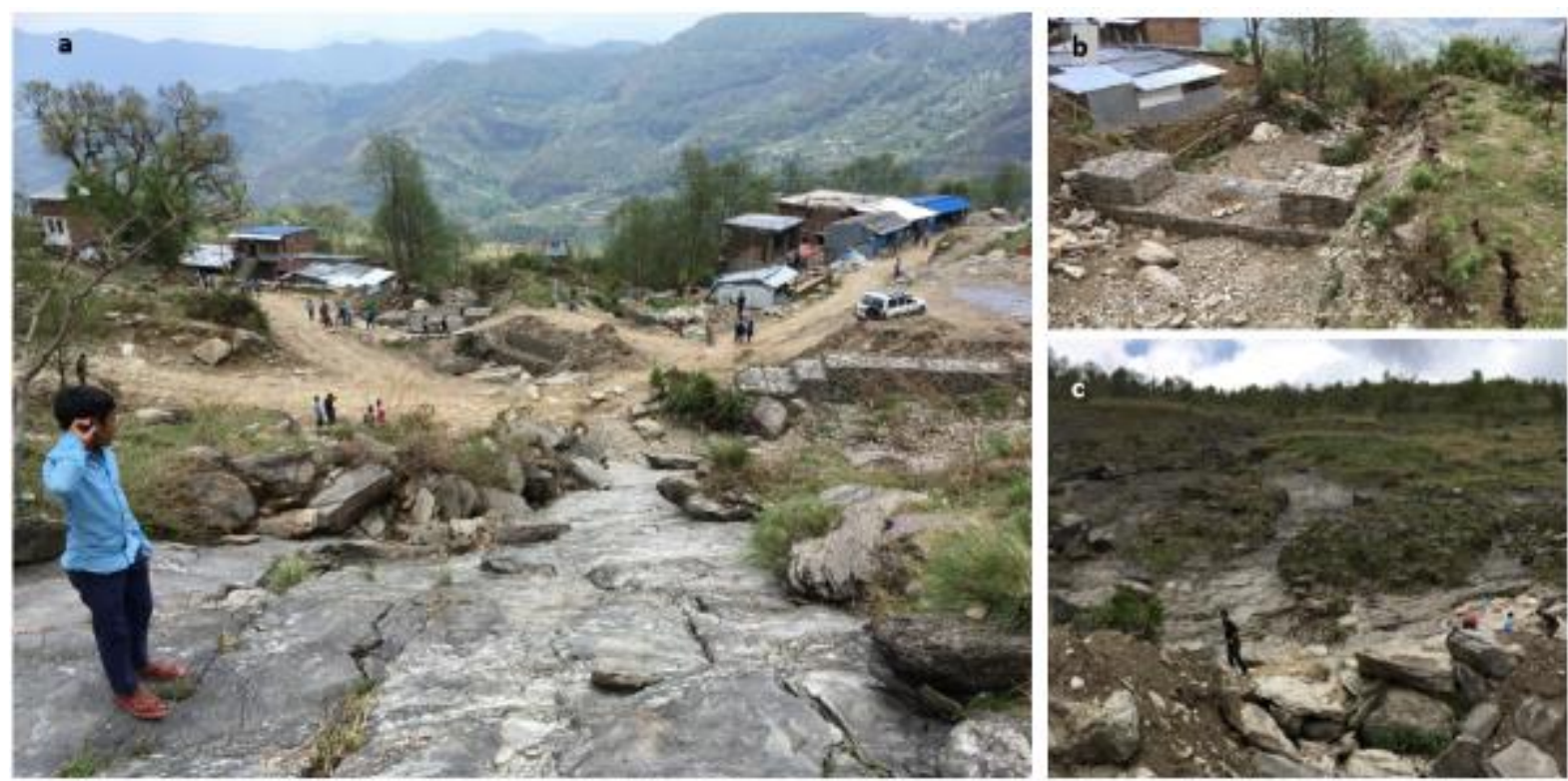

Figure 8. The community of Phulkarka is at risk from high stream flow, overland flow and landsliding. (A) The slopes above the community are widely stripped of their soil cover and this results in very rapid and destructive floods during the monsoon. A system of gabions is being constructed to direct flows and reduce their erosion potential. (B) A close-up of a gabion structure intended to control flow in a stream channel. Bank stability is still very poor (large cracks are visible) and housing is in very close proximity to the stream channel. (C) an view of the slopes above the community highlights the absence of suitable slope and vegetation cover. It is reported that the treeline visible to the left were planted by the community in an attempt to stabilise a landslide.

The urban context of Chautara has also led to a shortage of space for building, so that people are increasingly having to build on or close to steeper slopes (Fig. 9D, E). The highly fractured and, in places, weathered nature of the bedrock in Chautara (Fig. 9C) was also reported to be challenge for people digging foundations for their reconstructed homes:

"that was the most difficult bit - digging the trench. The municipality engineer instructed us to dig it four and a half feet down".

(Female interviewee, Chautara) 


\section{Landsystem 14 - Past glaciated mountainous terrain, moderate to steep slopes}

The previous landsystems were described by Carson et al. (1986) as positioned in the 'Middle Mountain' region. Landsystem 14 is positioned in what they classify as the 'High Mountain' region with characteristically steeper and higher slopes formed in harder bedrock.

The rural community at Chimchok (elevation $1525 \mathrm{~m}$ ) is positioned on a broad valley shoulder that is characterised by relatively gentle slopes $\left(10\right.$ to $\left.20^{\circ}\right)$ gradually transiting upwards to steeper slopes along the ridge (1875-2500 m elevation) above this setting, and a deep, steeply incised ravine (dropping some 500-700 m in elevation) below. The rural communities of Ri Gau (elevation $1500 \mathrm{~m}$ ) and Dharka (elevation $1575 \mathrm{~m}$ ) are located on steep, mid-slope section.
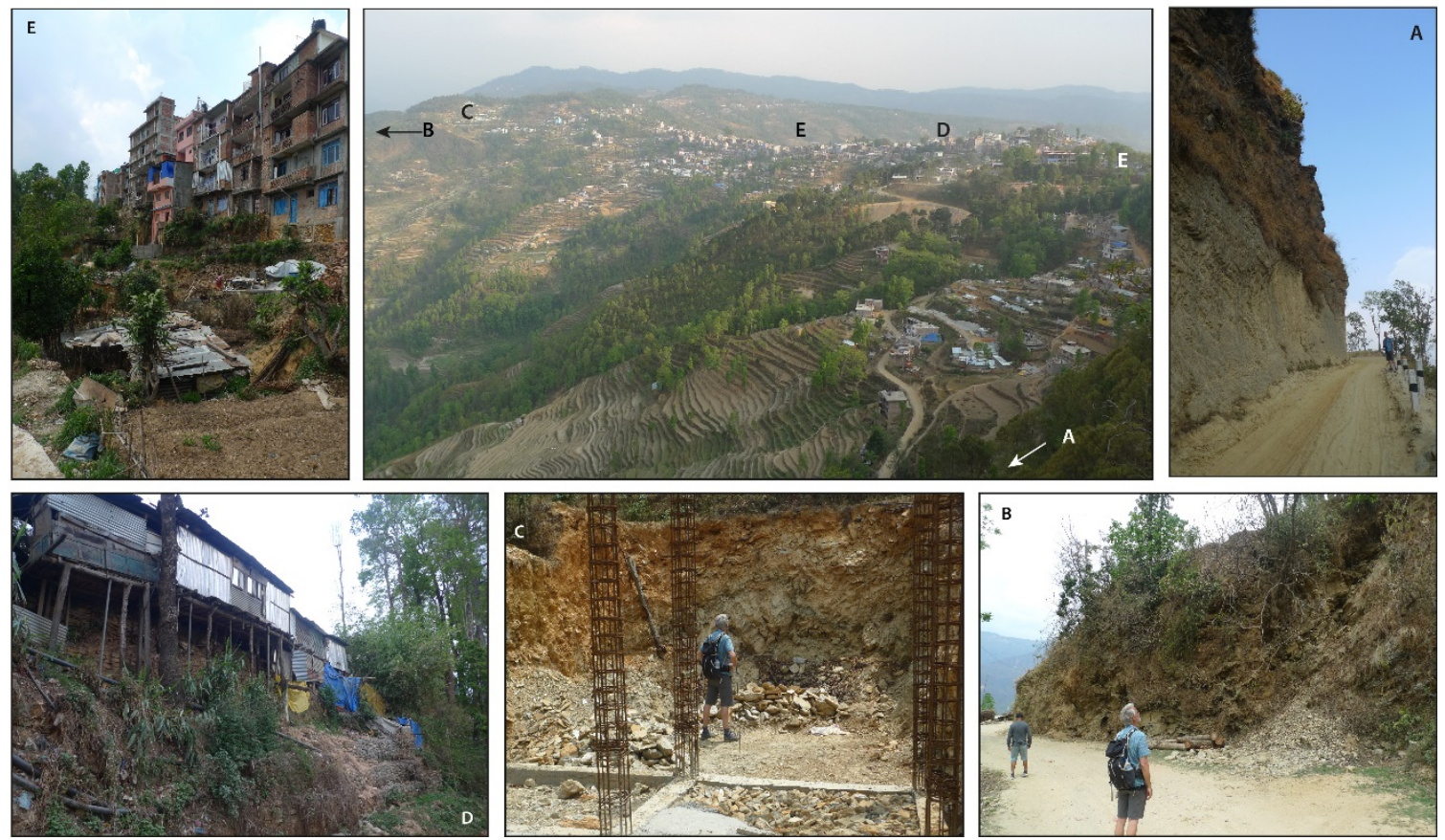

Figure 9. Central image provides a context for the ridge-top urbanised community of Chautara. (A) Vulnerable and exposed access road beneath a steep rock wall to the north of the town. (B) An active landslide at the southern edge of the town. Local people reported that the large block moves every monsoon and impacts the road. (C) Conditions for excavating foundations are challenging. The surface material comprises weathered and fractured bedrock, and has been affected by slope movement. (D) Informal housing at a slope edge, illustrating the challenges of building where flat space is limited. (E) There is a lack of flat building space at the town edge and buildings are constructed several storeys high at the slope edge. British Geological Survey (c) UKRI 2020. 
Of the communities we visited, Chimchok and Ri Gau were hardest to reach by car or truck. Ri Gau was, at the time of the field visit, not yet connected to a road transport network although efforts were underway to extend the road from Chimchok. However, steep slopes, deep ravines and exposed rock faces create substantial impediments for road construction in this region. The exposed rock slopes in the upper reaches of this landsystems were reported to be much more unstable in the monsoon seasons following the earthquake, making it very hazardous to pass from community to community where paths and small roads cross beneath rocky outcrops. One farmer in Ri Gau reported that:

"We used to be able to walk without fear to our neighbours, but now we need to be very careful when it rains. The rocks have large gaps and there are many more boulders falling down the hill."

(Interviewee, Ri Gau)

Many people we met in these communities were still very worried about the potential for further hazard events where they were living (e.g. the occurrence of further landslides during the monsoon) and were keen to move somewhere else. One person from a focus group in this landsystem said that:

"(Before the earthquake) we were happier here despite the hardships, now we cannot live here because we are afraid that we will die here if we live here for long."

(Interviewee, Ri Gau)

Others said that "life was good" before the earthquake and the community had not been affected by landslides. However, the earthquake triggered several landslides in close proximity to the community and ongoing and expanding slope instability was reported as having an increasing impact. In nearby communities where slopes had become unstable, some people had approached the government for support with relocation but this had been slow to materialise. Fear of what could happen if there was another earthquake was also holding people back. For example, when asked about restoring damaged farming terraces, one interviewee said that he was afraid that if they were to rebuild the terraces, it would be in vain if there were another earthquake.

\section{Discussion}

Our findings (summarised in Tables 1 and 2 ) show that the physical environment strongly influences self-recovery. While each disaster is unique and the way recovery happens in a particular setting will be shaped by a multitude of factors (e.g. food supply, political context, community institutions, climate, etc.), the examples presented here do provide some insight into the barriers to selfrecovery that may manifest in dynamic, multi-hazard environments. They also suggest that certain barriers (such as groundwater lowering and crop susceptibility in the dry season, flooding, or slope instability affecting access) are prevalent in particular landsystems and are often associated with known, recurring weather events (and might therefore also be anticipated and planned for).

Since the 2010 Haiti earthquake, 'area-based' humanitarian programmes (also referred to as settlement or neighbourhood approaches) have become popular, and are seen as particularly appropriate for urban responses. A geographical limit is defined and the needs of the population assessed in a holistic manner through a participatory process (Parker and Maynard, 2015). 
Identifying and addressing the geomorphological or environmental issues that communities perceive to be barriers to their own recovery efforts in the particular landsystem in which a district or community is located would seem to be potentially well aligned with an area-based approach. Further work is needed to determine the extent to which barriers to self-recovery could be categorised generically for specific landsystems and therefore the type of support people who selfrecover in a particular landsystem might need can be anticipated.

Despite the differences in the disaster contexts, there are key barriers to self-recovery that originate in the physical environment that are common to most of the landsystems considered in this research:

- People experience frequent, relatively localised hazards during recovery, which have a significant impact on their ability to recover (extensive risk)

- Disruption to transport infrastructure/access routes as a result of flooding, landslides, etc., also inhibits recovery

- Challenges relating to natural water supply. This can be either limited capacity to deal with the effects of dry periods or seasonal episodes of extreme precipitation.

All of these effects are exacerbated by the effects of longer term environmental/climate change, which a number of communities recognised that they are struggling to adapt to.

This situation is further complicated by the need to make risk-informed decisions but with potentially limited information. There is a need for all these barriers (Tables 1 and 2) to be addressed because of their negative impact on people's health and livelihoods, and on building back better. A range of responses is necessary since tackling these barriers may not be within the capacity of an individual, family or community and may require engineering expertise or heavy equipment. Furthermore, as we have seen, having to clear roads, restore agricultural land or walk some distance to get water diverts people from restoring their shelters, maintaining their livelihoods and rebuilding their lives.

Although we are not arguing that these are the most important barriers that someone who is selfrecovering might face, tackling these barriers could be an effective way for the humanitarian sector to support self-recovery in dynamic, multi-hazard contexts. At present, the support to family and community self-recovery from the humanitarian sector can be two-fold. There can be 'direct' support to people who are self-recovering. Typically, for a shelter programme, this might be in the form of cash, technical assistance or guidance, and materials. Identifying and tackling the barriers within the wider context that hinder self-recovery is another way to support the process, which is classed here as 'indirect' support. To take the shelter sector again, these barriers might include land tenure issues, a lack of appropriate technical support, and legal issues among many others.

We have developed a preliminary conceptual framework based on the findings from the three disaster contexts, which shows how self-recovery in dynamic, multi-hazard landscapes could be supported by the humanitarian sector. This is presented in Figure 10. It summarises the possible actions that could be taken using a similar 'direct' and 'indirect' categorisation to that discussed above. In terms of direct support, our findings show a need for scientific and technical information that enables people to decide how to respond to landscape changes or potential threats (such as advice regarding slope stability and the significance of cracks appearing in the land, or the potential to focus resources on drilling deeper water wells in communities where geology is more susceptible to groundwater level fluctuations). Community engagement is vital to fully understand the extensive risks associated with the physical environment to which people are exposed. There are indications 
that many people need very local-scale information that complements their own knowledge and that is provided in an ongoing 'responsive' fashion starting very soon after a disaster. People who live in these environments already have a great amount of knowledge and experience of the landscape so additional scientific or technical information needs to be provided in a way that recognises and complements this. Having both indigenous and technical knowledge may help people to make more informed decisions and choices as they recover. This would not be without its challenges. Experience in the shelter sector shows that just giving families technical information or training is not enough and that accompaniment may be necessary (e.g. Flinn and Llorens Echegaray, 2016). Here we take 'accompaniment' to mean supervision, encouragement and hands-on advice so that people can make informed decisions and be confident that they are correctly interpreting and applying the geoscience information they receive. Responding to these needs would be forms of 'direct' support. Indirect support would then be to address barriers to self-recovery that exist within the physical landscape in which self-recovery happens, i.e. managing geohazard risk or tackling water and infrastructure issues.

The direct and indirect support to self-recovery that might be offered by the shelter sector now has a strong focus on building (providing cash, technical assistance and materials, and tackling a range of institutional issues relating to rebuilding). Providing the support that focusses on addressing some of the barriers related to self-recovery that there may be a dynamic, multi-hazard environment in the way we have posited is therefore very different to this and presents some challenges that need to be better understood and overcome. These include (1) a lack of geoscience expertise within the humanitarian sector, (2) lack of available or accessible geoscience information at a local scale that people who self-recover can use to make risk-informed decisions (recognising the limited choices that might be available to them) and (3) relatively undeveloped links between the humanitarian sector and the geoscience community. We discuss these points further below but each requires further investigation so that the situation may be better understood.

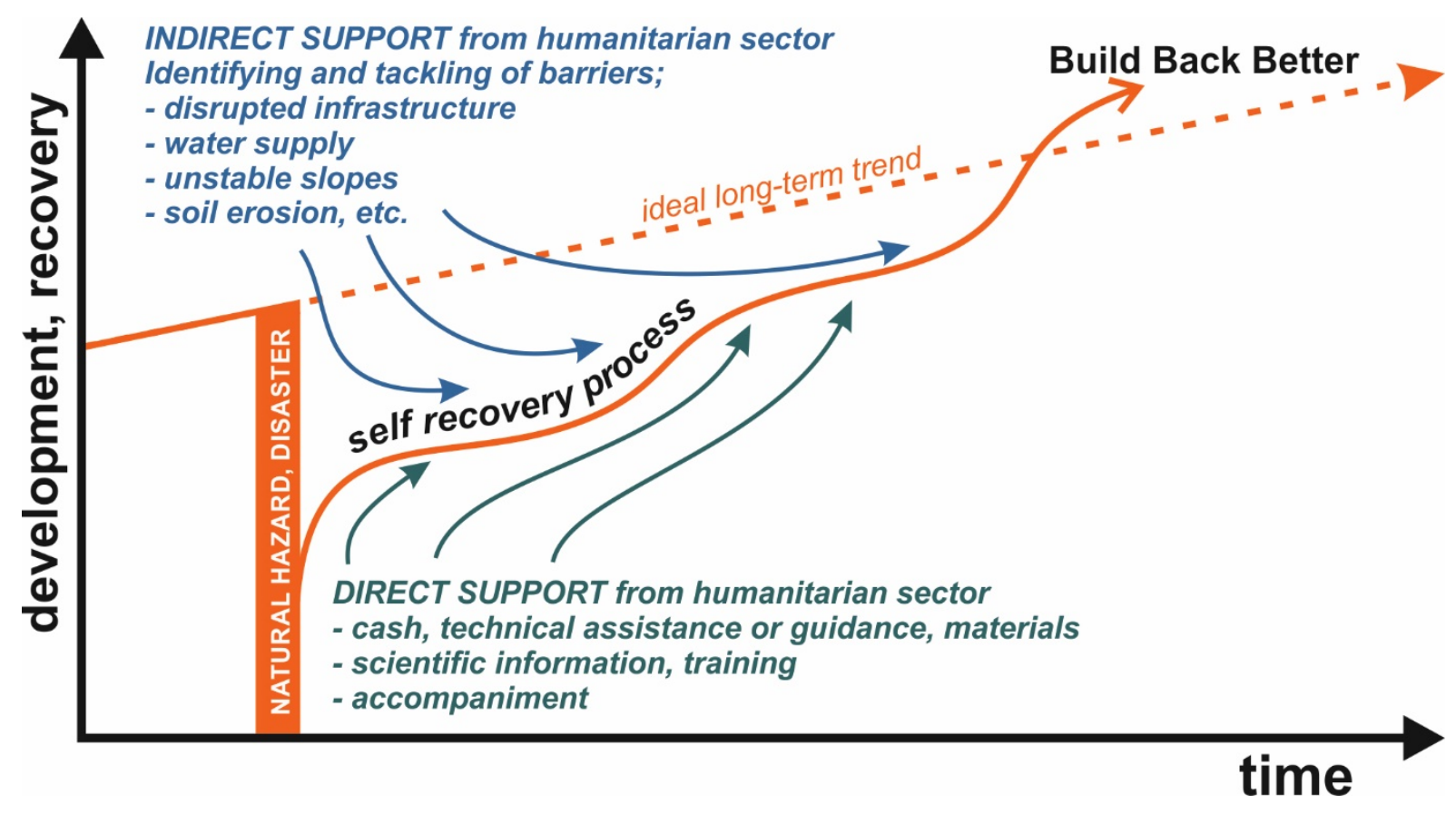


Figure 10. A preliminary conceptual framework showing self-recovery in a dynamic landscape and how it could be supported. Blue arrows represent support alongside the self-recovery process.

\section{Challenges to providing direct support}

Geoscience expertise in the humanitarian sector is not as common as expertise in health, agriculture or engineering, for example, so increasing geoscience capacity would be necessary for these organisations to be able to play a greater role in providing geoscience information and supporting people to use it. Recruiting more staff with a geoscience background who have some understanding of how to read and understand the landscape and use geoscience information might be one way to do this. Research is necessary to assess the current geoscience capacity within humanitarian organisations and how it could be increased.

It is also necessary to better understand the scale and nature of the demand for geoscience information from the point-of-view of those who are recovering. The extent to which this demand could be met by local geoscientists might be limited by factors such as availability of staff, data, equipment, etc. The possibility also exists that the operational constraints that many geoscientists face, particularly in developing countries, may be compounded by the fact that they themselves may have been affected by the disaster, which will limit the extent to which they can support selfrecovery or influence decisions that would support self-recovery. Again, further research is necessary to understand how this could be managed and what support geoscientists in other countries could provide at such times.

These forms of direct support also require relationships between geoscientists and the humanitarian sector to be strengthened. In each disaster-affected country, there will be a community of skilled geoscientists with whom to engage who have detailed knowledge of the geological settings in which people are recovering and some of the challenges they will likely face. Therefore, relationships between geoscientists and the humanitarian sector would be beneficial. The findings presented here are the result of a collaboration between geoscientists, humanitarian practitioners, social scientists and engineers. The relationships and understanding of each other's points-of-view and ways of working (both as individuals and in our respective sectors) have taken time and effort to build. Building these kinds of relationships between humanitarian actors and local geoscientists in the immediate aftermath of a disaster is likely to be very challenging and points to the need for action now to build relationships between agencies who would potentially be involved in the response and local geoscientists. People affected by past disasters who are in the process of self-recovering should also be part of this conversation since learning from their knowledge and experience is vital for geoscientists and humanitarian practitioners to support self-recovery effectively in dynamic, multihazard environments.

\section{Providing indirect support}

Possible forms of indirect support to self-recovery that could be offered might include unblocking roads, stabilising slopes or helping to restore water supplies and irrigation systems. The cases investigated in this study show that damage to infrastructure (roads, bridges, water supply, electricity supply, etc.) caused by frequent (often localised) hazard events such as floods and landslides seem to have a particularly severe effect on the self-recovery process (e.g. increasing the cost of rebuilding and damaging livelihoods). Often, the scale of the impact of these events (e.g. stabilising a large slope) appeared to be greater than a community could tackle and where external support could make things easier, especially if government resources are already stretched. Dealing 
with these larger scale issues would allow people to concentrate on rebuilding their homes and could be another way for the humanitarian sector to support self-recovery.

The need for the reinstatement of essential services and restoration of damaged infrastructure is included in the Humanitarian Emergency Response Review (HERR, 2011). This British Government policy paper states that these tasks are 'outside the skill set of NGOs or UN agencies, and funding and procurement barriers often prevent such skills being accessed in a timely fashion from the private sector' ( $p$ 37). Nonetheless, the humanitarian sector does undertake some of these tasks like rubble removal and clearing drainage channels and roads, often through cash-for-work programmes. Water is frequently trucked into areas as part of a humanitarian response but is almost always for essential needs such as drinking, cooking and washing. Providing this type of support would potentially help to create an environment that supports self-recovery.

\section{Conclusions}

Using three disaster case studies, we have shown that the environment can have a profound effect on self-recovery. The main barriers to self-recovery are the need to respond to frequent, relatively localised hazards (extensive risk), disruption to transport infrastructure/access routes as a result of flooding, landslides, etc., and challenges surrounding water supply with limited capacity to deal with the effects of dry periods or seasonal precipitation extremes. None of what we have found is inconsistent with what is already set out in the World Bank's PDNA guidelines or in the Sphere Standards. However, the findings presented here do show some of the detail that lies below these broad recommendations. In particular, they give a community/household-scale perspective on some of the issues that must be considered in order to support self-recovery in dynamic landscapes where one must continually respond to the frequently changing environment.

We have offered some suggestions about how these barriers to self-recovery might be tackled through direct and indirect support. For these ideas to be implemented, some significant capacity, information and logistical challenges in the geoscience and humanitarian sectors need to be better understood and overcome. These relate to the availability of geoscience expertise, availability and accessibility of technical information at the appropriate scale, and relatively weak links between the humanitarian and geoscience communities (generally speaking).

Investigation of how these suggestions could be implemented is needed urgently not least because this kind of direct and indirect support to self-recovery may potentially influence longer-term outcomes (this in itself warrants further research). It is vital to avoid situations where rapidly implemented measures do not adequately account for, or manage, the potential impacts that the physical environment can have on recovery and future development. That said, in a disaster situation, there is generally little time, data or opportunity to assess the long-term implications of a particular course of action and so preparedness for supporting self-recovery (in terms of building relationships, capacity strengthening and assembling relevant technical information at an appropriate scale) becomes key to achieving an optimal outcome. If the ambitions of the Sendai Framework for Disaster Risk Reduction are to be realised, there should be a concerted joint effort by humanitarian practitioners and geoscientists, working closely with recovering communities, to learn from past disasters and address these issues together so that all actors, including the humanitarian sector, are better able to support people who self-recover in dynamic, multi-hazard environments in the future.

\section{Acknowledgements}

We thank all the people we met and spoke to during the fieldwork whose experiences and insights we have learned from. We are very grateful to the local teams in Nepal and the Philippines, and the 
staff from CARE Philippines and CARE Nepal who facilitated our fieldwork. Without them, this research would not have been possible. We are also grateful to Tom Newby for his guidance and support throughout this work. This work was supported by the Global Challenges Research Fund through the NERC-ESRC-AHRC Building Resilience programme (grant NE/P016200/1) and the British Academy Cities and Infrastructure programme (grant Cl170172). We also thank Martin Smith and Melanie Duncan from BGS for their insightful reviews that significantly improved this paper. In addition, we are grateful to the three anonymous reviewers whose comments also helped to improve the paper. This work is published with the permission of the Executive Director of the British Geological Survey.

\section{References}

Anhorn, J., Lennartz, T. and Nüsser, M., 2015. Rapid Urban Growth and Earthquake Risk in Musikot, Mid-Western Hills, Nepal, Erdkunde, 69(4), pp.307-325.

Bhaby, Z., 2015. Nepal Earthquake Recovery Monitoring Assessment, https://www.sheltercluster.org/nepal-earthquake-2015/documents/nepal-earthquake-recoverymonitoring-assessment (last accessed 7 May 2020).

Bilham, R., Gaur, V.K. and Molnar, P., 2001. Himalayan seismic hazard. Science, 293(5534), pp.14421444.

Carson B, Shah PB and Maharjan PB 1986. Land Systems Report, the soil landscapes of Nepal, HMG of Nepal Land Resource Mapping Project carried out by Kenting Earth Sciences Limited, Kathmandu, Nepal [in Dijkshoorn and Huting 2009].

Centre for Disease Control and Prevention, Chikungunya Virus, https://www.cdc.gov/chikungunya/index.html_(last accessed 30 March 2020).

Dijkshoorn, J.A. and Huting, J.R.M., 2009. Soil and terrain database for Nepal. Report 2009/01 (available through: http://www.isric.org), ISRIC - World Soil Information, Wageningen (29 p. with data set).

Eco, R.N., Aquino, D.T., Lagmay, A.M.F., Alejandrino, I., Bonus, A.A., Escape, C.M., Felix, R., Ferrer, P.K., Gacusan, R.C., Galang, J. and Llanes, F., 2015. Landslide and debris flow susceptibility mapping of Leyte Province, Philippines using remote sensing, numerical modelling, and GIS. Journal of the Philippine Geoscience and Remote Sensing Society, 1(1), pp.53-71.

Elliott, J., Jolivet, R., González, P. J., Avouac, J.-P., Hollingsworth, J., Searle, M. P., and Stevens, V. L., 2016. Himalayan megathrust geometry and relation to topography revealed by the Gorkha earthquake, Nature Geoscience, 9, pp.174-180.

FAO, 2017. El Niño and La Niña in the Philippines. Food and Agriculture Organization of the United Nations, http://www.fao.org/3/a-i6775e.pdf (last accessed 30 March 2020).

Flinn, B., and Llorens Echegaray, M., 2016. Stories of Recovery: CARE Philippines post Haiyan/Yolanda shelter response, https://insights.careinternational.org.uk/media/k2/attachments/CARE Stories-of-recovery PostHaiyan-Yolanda-shelter-report 2016.pdf (last accessed 7 May 2020).

Froude, M.J. and Petley, D., 2018. Global fatal landslide occurrence from 2004 to 2016. Natural Hazards and Earth System Sciences, 18, pp.2161-2181. 
Gnyawali, K.R., Maka, S., Adhikari, B.R., Chamlagain, D., Duwal, S. and Dhungana, A.R., 2016, April. Spatial implications of earthquake induced landslides triggered by the April 25 Gorkha earthquake Mw 7.8: preliminary analysis and findings. In International conference on earthquake engineering and post disaster reconstruction planning 24-26 April, 2016, Bhaktapur, Nepal, pp. 50-58.

Griffiths, J.S. 2017. Technical note: Terrain evaluation in Engineering Geology, Quarterly Journal of Engineering Geology and Hydrogeology, 50 (1), pp.3-11.

Global Assessment Report, 2015. Making Development Sustainable: the Future of Disaster Risk Management, https://www.preventionweb.net/english/hyogo/gar/2015/en/home/index.html (last accessed 30 March 2020).

Hearn, G.J. and Shakya, N.M., 2017. Engineering challenges for sustainable road access in the Himalayas. Quarterly Journal of Engineering Geology and Hydrogeology, pp.qjegh2016-109.

Humanitarian Emergency Response Review (HERR),

2011https://assets.publishing.service.gov.uk/government/uploads/system/uploads/attachment_dat a/file/67579/HERR.pdf (last accessed 30 March 2020).

ICVA, 2017. The Grand Bargain: everything you need to know, ICVA Briefing Paper, February 2017, https://www.agendaforhumanity.org/sites/default/files/The\%20Grand\%20Bargain Everything\%20Y ou\%20Need\%20to\%20Know\%20\%28ICVA\%29 0.pdf (last accessed 30 March 2020).

Kargel, J.S., Leonard, G.J., Shugar, D.H., Haritashya, U.K., Bevington, A., Fielding, E.J., Fujita, K., Geertsema, M., Miles, E.S., Steiner, J. and Anderson, E., 2016. Geomorphic and geologic controls of geohazards induced by Nepal's 2015 Gorkha earthquake. Science, 351(6269), p.aac8353.

Lagmay, A.M.F., Agaton, R.P., Bahala, M.A.C., Briones, J.B.L.T., Cabacaba, K.M.C., Caro, C.V.C., Dasallas, L.L., Gonzalo, L.A.L., Ladiero, C.N., Lapidez, J.P. and Mungcal, M.T.F., 2015. Devastating storm surges of Typhoon Haiyan. International Journal of Disaster Risk Reduction, 11, pp.1-12.

Liu, Q., Ruan, X. and Shi, P., 2011. Selection of emergency shelter sites for seismic disasters in mountainous regions: Lessons from the 2008 Wenchuan Ms 8.0 Earthquake, China. Journal of Asian Earth Sciences, 40(4), pp.926-934.

Maly, E., 2018. Building back better with people centered housing recovery, International Journal of Disaster Risk Reduction, 29, pp.84-93.

Mas, E., Bricker, J., Kure, S., Adriano, B., Yi, C., Suppasri, A. and Koshimura, S., 2015. Field survey report and satellite image interpretation of the 2013 Super Typhoon Haiyan in the Philippines. Natural Hazards \& Earth System Sciences, 15(4), pp. 805-816.

MGB, 2015a. Detailed Landslide and Flood Hazard Map of La Paz, Burauen and Julita, Leyte, Philippines 3922-I-9 Calabnian Quadrangle; Department of Environment and Natural ResourcesMines and Geoscience Bureau (MGB), Lands Geological Survey Division: Quezon City, Philippines, 2015.

MGB 2015b. Mines and Geoscience Bureau (MGB). Detailed Landslide and Flood Hazard Map of Pastrana, Jaro and Alangalang, Leyte, Philippines 3913-II-12 Patong Quadrangle; Department of Environment and Natural Resources-Mines and Geoscience Bureau (MGB), Lands Geological Survey Division: Quezon City, Philippines, 2015.

MGB, 2015c. Mines and Geoscience Bureau (MGB). Detailed Landslide and Flood Hazard Map of Santa Fe, Palo and Alang-Alang, Leyte, Philippines 3923-II-9 Bulod Quadrangle; Department of 
Environment and Natural Resources-Mines and Geoscience Bureau (MGB), Lands Geological Survey Division: Quezon City, Philippines, 2015.

MGB, 2015d. Mines and Geoscience Bureau (MGB). Detailed Landslide and Flood Hazard Map of Tabuk (Capital), Kalinga, Philippines 3925-I-9 Calanan Quadrangle; Department of Environment and Natural Resources-Mines and Geoscience Bureau (MGB), Lands Geological Survey Division: Quezon City, Philippines, 2015.

Moss, R.E., Thompson, E.M., Scott Kieffer, D., Tiwari, B., Hashash, Y.M., Acharya, I., Adhikari, B.R., Asimaki, D., Clahan, K.B., Collins, B.D. and Dahal, S., 2015. Geotechnical effects of the 2015 magnitude 7.8 Gorkha, Nepal, earthquake and aftershocks. Seismological Research Letters, 86(6), pp.1514-1523.

Newby, T., 2015. CARE Philippines Typhoon Haiyan shelter recovery project evaluation, https://reliefweb.int/report/philippines/care-philippines-typhoon-haiyan-shelter-recovery-projectevaluation (last accessed 7 May 2020).

NDRRMC, 2014. Final report re effects of Typhoon "Yolanda" (Haiyan). National Disaster Risk Reduction and Management Council, 65 pp.

NDRRMC, 2016. SitRep No. 09 re Preparedness measures and effects of Super Typhoon "Lawin" (I.N. Haima). National Disaster Risk Reduction and Management Council, 7 pp.

National Planning Commission. Nepal Earthquake 2015, Post-disaster Needs Assessment 2015. Kathmandu: National Planning Commission, 2015.

NOAH 2018. Nationwide Operational Assessment of Hazards, accessed $20^{\text {th }}$ December 2018. http://noah.up.edu.ph/\#/

OCHA, 2016. Philippines: destructive tropical cyclones from 2006 to 2016, https://reliefweb.int/sites/reliefweb.int/files/resources/ocha_phl_destructive_typhoons_2006_to_2 016.pdf.

OCHA Regional Office for Asia Pacific, 2011. PHILIPPINES: Natural Hazard Risks, issues 01 March 2011, https://reliefweb.int/sites/reliefweb.int/files/resources/map 1301.pdf (last accessed 21 February 2019).

Ong, J.M., Jamero, M.L., Esteban, M., Honda, R. and Onuki, M., 2016. Challenges in build-back-better housing reconstruction programs for coastal disaster management: case of Tacloban City, Philippines. Coastal Engineering Journal, 58(01), p.1640010.

Parker, E., and Maynard, V., 2015, Humanitarian response to urban crises: a review of area-based approaches, IIED Working Paper, IIED, London.

Parrack, C., Flinn, M. and Massey, M., 2014. 'Getting the message across for safer self-recovery in post-disaster shelter', Open House International 39(3): pp.47-58.

Paudyal, P., Bhuju, D.R. and Aryal, M., 2015. Climate change dry spell impact on agriculture in Salyantar, Dhading, central Nepal. Nepal J. Sci. Technol, 16, pp.59-68.

Petley, D.N., Hearn, G.J., Hart, A., Rosser, N.J., Dunning, S.A., Oven, K. and Mitchell, W.A., 2007. Trends in landslide occurrence in Nepal. Natural hazards, 43(1), pp.23-44.

PHIVOLCS, 2008. Active and Potentially Active Volcanoes of the Philippines. Map accessed from website: https://www.phivolcs.dost.gov.ph/index.php/volcano-hazard/volcanoes-of-the-philippines 
Rimal B., Zhang, L.F., Fu, D.J., Kunwar, R and Zhai, Y.G. (2017). Monitoring urban growth and the Nepal earthquake 2015 for sustainability of Kathmandu Valley, Nepal. Land, 6(42), 23p.

REACH, 2013. http://www.reachresourcecentre.info/system/files/resource-documents/lea.macias17022014-091814-Haiyan\%20Typhoon\%20Shelter-WASH assessment Final\%2OReport validatedformatted.pdf

READY Project. 2009. Volcanic hazard map of Leyte. 1:150,000 scale.

Roback, K., Clark, M.K., West, A.J., Zekkos, D., Li, G., Gallen, S.F., Chamlagain, D. and Godt, J.W., 2018. The size, distribution, and mobility of landslides caused by the 2015 Mw7. 8 Gorkha earthquake, Nepal. Geomorphology, 301, pp.121-138.

Sapkota, S.N., Bollinger, L., Klinger, Y., Tapponnier, P., Gaudemer, Y. and Tiwari, D., 2013. Primary surface ruptures of the great Himalayan earthquakes in 1934 and 1255. Nature Geoscience, 6(1), p.71.

Saunders, G., 2004. Dilemmas and challenges for the shelter sector: lessons learned from the sphere revision process. Disasters, 28(2), pp.160-175.

Schofield, H., Lovell, E., Flinn, B., and Twigg, J., 2019. Barriers to urban shelter self-recovery in Philippines and Nepal: lessons for humanitarian policy and practice, Journal of the British Academy, 7(s2), 83-107.

Shaw, R., Uy, N., and Baumwoll, J., 2008. Indigenous knowledge for disaster risk reduction: Good practices and lessons learned from experiences in the Asia-Pacific region, UNISDR report, http://www.unisdr.org/files/3646 IndigenousKnowledgeDRR.pdf (last accessed 21 August 2017).

Sharma, K., Apil, K.C., Subedi, M., \& Pokharel, B., 2018a. Post Disaster Reconstruction after 2015 Gorkha Earthquake: Challenges and Influencing Factors. Journal of the Institute of Engineering, 14(1), 52-63. https://doi.org/10.3126/jie.v14i1.20068.

Sharma, K., Apil, K.C., Subedi, M. and Pokharel, B., 2018b. Challenges for reconstruction after Mw 7.8 Gorkha earthquake: a study on a devastated area of Nepal. Geomatics, Natural Hazards and Risk, 9(1), pp.760-790.

Shrestha, A. B., Bajracharya, S. R., Kargel, J. S., Kanal, N. R., 2016. The impact of Nepal's 2015 Gorkha earthquake-induced geohazards. International Centre for Integrated Mountain Development (ICIMOD), 2016.

Stephenson, V., Finlayson, A., Miranda Morel, L. 2018. A risk-based approach to shelter resilience following flood and typhoon damage in rural Philippines. Geosciences, 8 (2), 76.

Takagi, H. and Esteban, M. 2016. Statistics of tropical cyclone landfalls in the Philippines: unusual characteristics of 2013 Typhoon Haiyan. Natural Hazards, 80, 211-222.

Twigg, J., Lovell, E., Schofield, H., Miranda Morel, L., Flinn, B., Sargeant, S., Finlayson, A., Dijkstra, T., Stephenson, V., Albuerne, A., Rossetto, T., and D'Ayala, D., 2017. Self-recovery from disasters: an interdisciplinary perspective, Overseas Development Institute Working Paper, 523.

Williams, J.G., Rosser, N.J., Kincey, M.E., Benjamin, J., Oven, K.J., Densmore, A.L., Milledge, D.G., Robinson, T.R., Jordan, C.A. and Dijkstra, T.A., 2018. Satellite-based emergency mapping using optical imagery: experience and reflections from the 2015 Nepal earthquakes. Natural Hazards and Earth System Sciences., 18, pp.185-205. 
World Bank, 2017a. Post-disaster needs assessment guidelines: environment (English). Post-disaster needs assessment guidelines: volume B. Environment. Washington, D.C.: World Bank Group.

http://documents.worldbank.org/curated/en/773111493642626075/Post-disaster-needsassessment-guidelines-environment (last accessed 30 March 2020).

World Bank, 2017b. Cross-cutting sector - disaster risk reduction (English). PDNA guidelines volume B: disaster risk reduction. Washington, D.C.: World Bank Group.

http://documents.worldbank.org/curated/en/120541493102189066/Cross-cutting-sector-disasterrisk-reduction (last accessed 30 March 2020). 